\title{
Enantioenriched quaternary $\alpha$-pentafluoroethyl derivatives of alkyl 1-indanone-2-carboxylates
}

\author{
Albert Granados, * Anna Ballesteros and Adelina Vallribera* \\ Chemistry Department and Centro de Innovación en Química Avanzada (ORFEO-CINQA), \\ Universitat Autònoma de Barcelona, Cerdanyola del Vallès, 08193 Barcelona (Spain)
}

ABSTRACT: An electrophilic enantioselective catalytic method for the $\alpha$-pentafluoroethylation of alkyl 1-indanone-2-carboxylates is described. Under the use of $\mathrm{La}(\mathrm{OTf})_{3}$ in combination with $(S, R)$-indanyl-pybox ligand good results in terms of yield and enantioselectivities were achieved (up to $89 \%$ ee). The reaction proceeds under mild conditions leading to the formation of enantioenriched quaternary centers. This methodology uses an hypervalent iodine(III)- $\mathrm{CF}_{2} \mathrm{CF}_{3}$ reagent and mechanistic investigations are consistent with the involvement of a radical pathway.

\section{INTRODUCTION}

Over the last years, the incorporation of fluorine and fluorine containing groups into organic molecules in order to change its physical, biological and chemical properties has become a powerful tool in drug design due to its favourable effects on pharmacological profiles. ${ }^{1}$ Among fluoroalkyl groups, ${ }^{2}$ the pentafluoroethyl $\left(\mathrm{CF}_{2} \mathrm{CF}_{3}\right)$, the bulkier analogue of $\mathrm{CF}_{3}$ group, is nowadays one of the most attractive groups ${ }^{3}$ in drug design. Due to its strong electronwithdrawing nature, a pentafluoroethylated drug would be less likely to be oxidized by P450 enzymes, leading to an increase of its metabolic stability. ${ }^{4}$ Additionally, the lipophilicity of the pentafluoroethyl group is comparable to the one of the recognized lipophilic pentafluorosulfanyl $\left(-\mathrm{SF}_{5}\right)$ group. On the whole, the presence of a pentafluoroethyl group in drugs can improve their biological activity due to the combination of a unique steric factor with an increased electronegativity, lipophilicity and metabolic stability. In this context, Fulvestrant (estradiol containing a side chain in with $\mathrm{CF}_{2} \mathrm{CF}_{3}$ group at the end) was approved by the FDA in 2002 as a second-line theraphy for advanced breast cancer in postmenopausal women with disease progression following antiestrogen therapy (Figure 1). ${ }^{5}$ Moreover, peptidyl pentafluoroethyl ketones have been reported to inhibit various enzymes, as for example, elastase and the hepatitis C virus N53 protease. ${ }^{6}$ In addition, some pentafluoroethyl ketones are powerful inhibitors of Group VIA Calcium-Independent Phospholipase A2 
proteases. $^{7}$ Recently, functionalisation of bicalutamide and enobosarm scaffold with pentafluorosulfanyl and pentafluoroethyl functionality lead to potent agents against prostate cancer (Figure 1). ${ }^{8}$
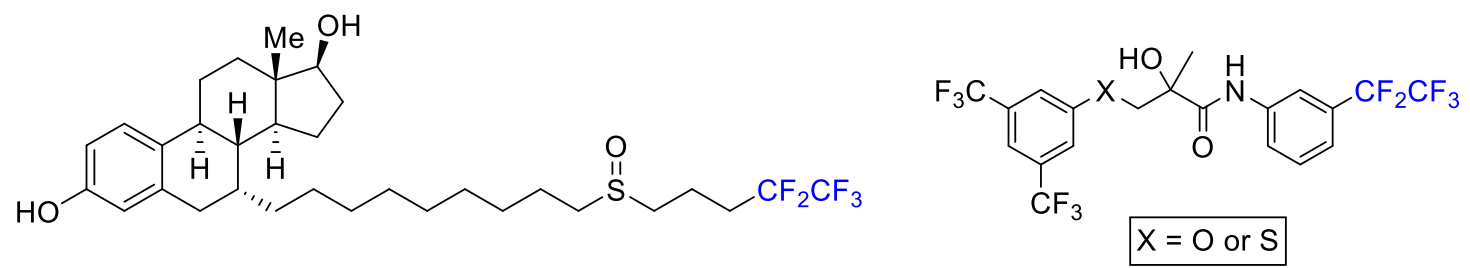

Figure 1. Pentafluoroethylated anticancer drugs

Despite the tremendous progress made in trifluoromethylation, ${ }^{9}$ synthetic methods for the introduction of longer perfluoroalkyl chains remain underdeveloped. In contrast to trifluoromethyl, the pentafluoroethyl moiety is still poorly present in drugs in part because the methods for the incorporation of $\mathrm{CF}_{2} \mathrm{CF}_{3}$ are scarcely documented. For example, for the pentafluoroethylation of a nucleophilic carbon centre alfa to carbonyl, only a few electrophilic pentafluoroethylating reagents have been described, ${ }^{10}$ such as (pentafluoroethyl)iodonium salts developed by Yaguposkii ${ }^{11}$ and Umemoto, ${ }^{12}$ and the hypervalent $\lambda^{3}$-iodane reagents $1^{13}$ and $\mathbf{2}^{14}$ (Scheme 1). Shen's group ${ }^{15}$ explored the direct pentafluoroethylation of $\beta$-keto esters using reagent 1 as electrophilic $\mathrm{CF}_{2} \mathrm{CF}_{3}$ source, $\mathrm{DBU}$ as base in $\mathrm{CH}_{3} \mathrm{CN}$ affording moderate to good yields (36-82\%). They showed that the bulkiness of the ester group lowered the yield. Togni's group performed the $\alpha$-perfluoroethylenation of a lactam-derived ketene silyl amide using 1, obtaining an excellent yield under $\mathrm{TMSNTf}_{2}$ catalyst (only one example). ${ }^{13 \mathrm{~b}}$

Moreover, while important catalytic enantioselective trifluoromethylation methods of the alfa carbon in carbonyl compounds have been developped, ${ }^{16}$ to date only one isolated asymmetric pentafluoroethylation of an oxindole has been reported (using $\mathrm{MgBr}_{2}$. $\mathrm{Et}_{2} \mathrm{O} /$ pybox and Togni's reagent 1 ) in a remarkable Katayev's work dedicated to the asymmetric trifluoromethylation of substituted oxindoles. ${ }^{17}$ As far as we know, there are no examples regarding the enantioselective $\alpha$-pentafluoroethylation of alkyl 1-indanone-2-carboxylates. In the past, our group have previously reported the asymmetric introduction of different electrophiles in $\beta$-dicarbonyl systems though lanthanide-pybox catalysis, from $\alpha$-amination ${ }^{18}$ to the most recent fluorination ${ }^{19}$ and trifluoromethylation ${ }^{20}$ reactions. Herein, we present our recent studies on the construction, for the first time, of enantioenriched pentafluoroethylated quaternary centres on alkyl 1-indanone-2-carboxylates using a combination of $\mathrm{La}(\mathrm{OTf})_{3}$ with pybox type ligands. 


\section{RESULTS AND DISCUSSION}

The first part of this work was dedicated to the synthesis of the reagents $\mathbf{1}$ and $\mathbf{2}$ (Scheme 1). The pentafluoroethylated benziodoxole 1 was fully synthesized as previously described ${ }^{15}$ through a nucleophilic substitution of 1-fluoro-1,3-dihydro-3,3-dimethyl-1,2-benziodoxole and $\mathrm{TMSCF}_{2} \mathrm{CF}_{3}$ in the presence of anhydrous $\mathrm{KF}$ in a $95 \%$ yield. On the other hand, the 1pentafluoroethyl-1,2-benziodoxol-3-(1H)-one reagent 2 was prepared in three steps from 2iodobenzoic acid in $54 \%$ overall yield. ${ }^{21}$<smiles>CC1(C)OI(F)c2ccccc21</smiles>

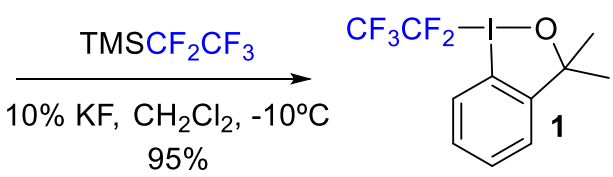
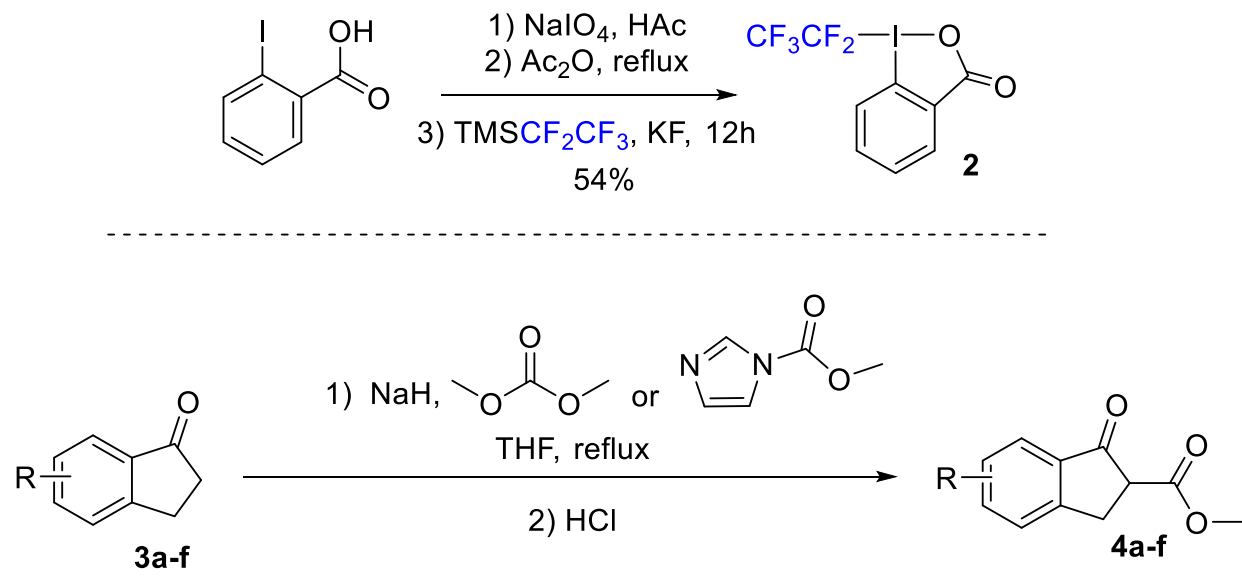

Scheme 1. Preparation of reagents 1, 2 and $\beta$-keto esters 4a-f.

Secondly, we proceeded with the synthesis of $\beta$-keto esters 4 . These substrates were chosen as a model for the catalytic system. Most of the acylation reactions of differently substituted commercial indanones $\mathbf{3}$ were accomplished using sodium hydride as a base and dimethylcarbonate as electrophile in dried THF. ${ }^{22}$ In some cases, methyl $1 H$-imidazole-1carboxylate was selected as electrophile in order to avoid aromatic nucleophilic substitutions of the methoxide. ${ }^{18 d}$ The reactions (Scheme 1 ) underwent successfully, giving the desired products in excellent yields ( $86 \%-100 \%$, see $\mathrm{SI}$ ). The bulkier $\beta$-keto esters $4 \mathrm{i}-\mathrm{I}$ were prepared by treatment of methyl analogue with the corresponding alcohol using catalytic amounts of $\mathrm{ZnO}$ in refluxing toluene. ${ }^{22}$

We very soon realized that $\mathbf{1}$ and $\mathbf{2}$ were not stable when kept in a closed vial on bench. Especially for 1, the white powder began to become slight yellow after a few days until 
reaching an intense orange colour after some weeks. The ${ }^{1} \mathrm{H}$ NMR of this yellowish solid revealed the degradation of $\mathbf{1}$ to 2-(2-iodophenyl)propan-2-ol (see SI). Thus, it must be kept in a vacuum desiccator. Others have observed decomposition of solutions of analogues of reagent 1 , possessing a group $\mathrm{CF}_{2} \mathrm{CF}_{2} \mathrm{R}$ instead of $\mathrm{CF}_{2} \mathrm{CF}_{3}$, over three days in chloroform or acetonitrile solutions. ${ }^{23}$

Then, we studied the pentafluoroethylation reaction of $\mathbf{4 a}$ as a model (Table 1 ). As said before, in 2016 Shen's group ${ }^{15}$ reported the direct pentafluoroethylation of some $\beta$-keto esters using hypervalent iodine (III)- $\mathrm{CF}_{2} \mathrm{CF}_{3}, 1$, and the organic base DBU (2 equiv.) obtaining $36-60 \%$ yields. We wanted to study the reaction using an inorganic base that could be separated by simple filtration. Potassium carbonate in THF yielded the product 5 a in a $23 \%$ yield. Other polar solvent as $\mathrm{CH}_{2} \mathrm{Cl}_{2}$ and $\mathrm{CH}_{3} \mathrm{CN}$ enhanced the yield (51 and 59\%, Table 1, entries 2 and 3). When using $\mathrm{Cs}_{2} \mathrm{CO}_{3}$ in $\mathrm{CH}_{3} \mathrm{CN}$ the yield was raised until $69 \%$. Disturbing is that neither higher nor lower temperatures improve the yield of $\mathbf{5 a}$. Changing the reagent $\mathbf{1}$ by $\mathbf{2}$ did not increase the reaction yield (Table 1, entry 5). Another way of activation of $\beta$-dicarbonyl compounds is the use of Lewis acids. Thus, following the idea of Katayev and Togni, ${ }^{13 b}$ magnesium bromide ethyl etherate (10\%) was used obtaining $5 \mathrm{a}$ in a $68 \%$ yield. With $\mathrm{La}(\mathrm{OTf})_{3}(10 \%)$ the pentafluoroethylated compound was obtained in a lower 59\% yield (entry 9). On the other hand, inspired by the racemic trifluoromethylations reactions developed by Cahard ${ }^{9 a}$ using the trifluoromethylcalconium salts, we added $n \mathrm{Bu}_{4} \mathrm{NI}$ but without higher great success. Finally, the organic base DIPEA was not a good selection for this reaction.

Table 1. Optimization of the $\alpha$-pentafluoroethylation reaction of 4 a.

\begin{tabular}{ccccccc}
\hline & & & & \\
\hline
\end{tabular}




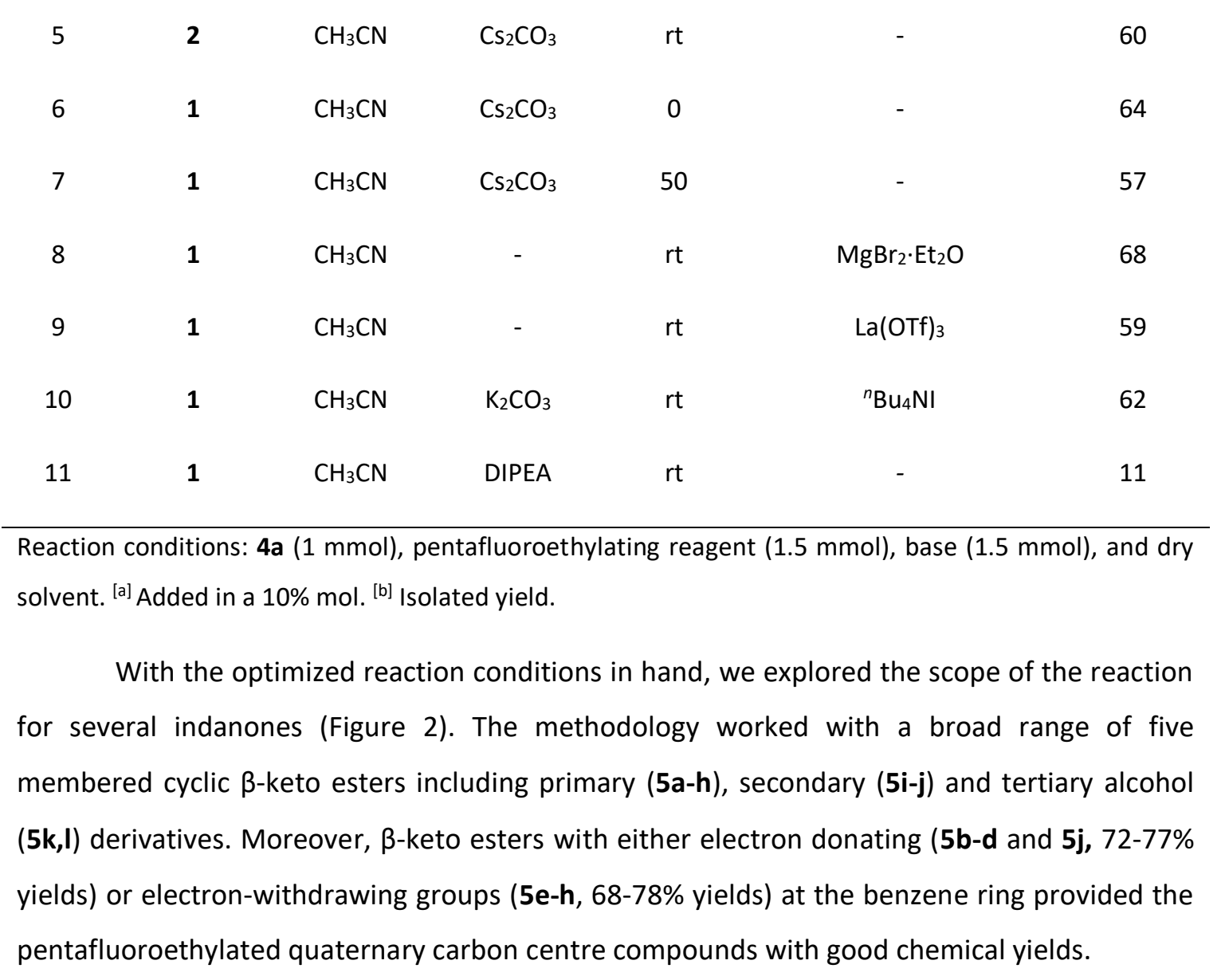




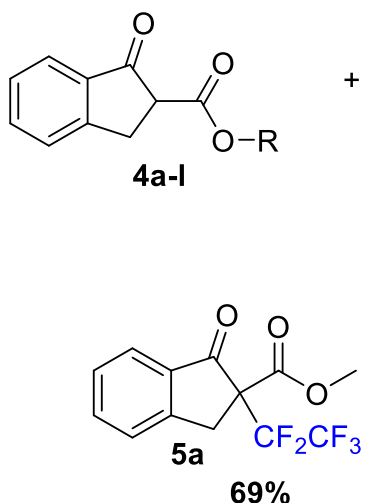

$69 \%$<smiles>COC(=O)C1(C(F)(F)F)Cc2cc(OC)c(OC)cc2C1=O</smiles><smiles>COC(=O)C1(C(F)(F)F)Cc2cc(F)cc(F)c2C1=O</smiles><smiles>CCC(CC)OC(=O)C1(C(F)(F)F)Cc2cc(OC)c(OC)cc2C1=O</smiles><smiles>CC1(C)OI(C(F)(F)F)c2ccccc21</smiles><smiles>COC(=O)C1(C(F)(F)F)Cc2ccc(C(C)(C)C)cc2C1=O</smiles>

$72 \%$<smiles>COC(=O)C1(C(F)(F)F)Cc2ccc(F)cc2C1=O</smiles><smiles>COC(=O)C1(C(F)(F)F)Cc2cccc(Br)c2C1=O</smiles><smiles>CC(C)(C)OC(=O)C1(C(F)(F)F)Cc2ccccc2C1=O</smiles><smiles>COC(=O)C1(C(F)(F)F)Cc2ccc(OC)cc2C1=O</smiles><smiles>COC(=O)C1(C(F)(F)F)Cc2ccc(C(F)(F)F)cc2C1=O</smiles><smiles>CCC(CC)OC(=O)C1(C(F)(F)F)Cc2ccccc2C1=O</smiles><smiles>O=C(OC1C2CC3CC(C2)CC1(C(F)(F)F)C3)C1(C(F)(F)F)Cc2ccccc2C1=O</smiles>

Scheme 2. Scope of the racemic $\alpha$-pentafluoroethylating reaction in alkyl 1-indanone-2carboxylates<smiles>c1cc(C2=N[C@H]3c4ccccc4C[C@H]3O2)nc(C2=N[C@H]3c4ccccc4C[C@H]3O2)c1</smiles><smiles>c1ccc(C2COC(c3cccc(C4=N[C@@H](c5ccccc5)CO4)n3)=N2)cc1</smiles><smiles>c1ccc(C2N=C(c3cccc(C4=N[C@@H](c5ccccc5)[C@H](c5ccccc5)O4)n3)O[C@@H]2c2ccccc2)cc1</smiles>

Figure 2. Pybox ligands used in the optimization of the electrophilic enantioselective pentafluoroethylation reaction.

Next, we studied the enantioselective version of this electrophilic reaction. In the first attempt, we selected $\mathbf{4} \mathbf{d}$ and $\mathbf{1}$ under the combination of europium (III) triflate and $(S, R)$ indanyl-pybox (L1, Figure 2) as catalyst at $-30^{\circ} \mathrm{C}$ (Table 2, entry 1). The enantiopure pybox ligand will act as a chiral ligand and base. Compound $\mathbf{5} \mathbf{d}$ was obtained in low yield and 
enantioselectivity. Next, we changed the metal, moving to yterbium, achieving the fluorinated product in good yield (76\%) and moderate enantioselectivity (45\%). Then, we performed the reaction changing the metal source to lanthanum (III) triflate and we afforded $\mathbf{5 d}$ in a $80 \%$ ee and good yield (entry 3). In order to improve these results, we moved to $(R, R)$-Ph-pybox (L2) and $(S, R)$-diPh-pybox (L3), but the reaction was worst in both terms of yield and ee (entries 4 and 5). We checked $\mathrm{CH}_{2} \mathrm{Cl}_{2}$ as solvent at $-78^{\circ} \mathrm{C}$, but acetonitrile at $-30^{\circ} \mathrm{C}$ gave better results (entry 3 vs 6). Performing the reaction at room temperature did not enhance the ee (entry 3 vs entry 7). Then, we used an automatic injector to make a slow addition of the pentafluorofluoroethylating agent 1 to the reaction mixture, affording the product with the same enantioselectivity but slightly lower yield (entry 3 vs entry 8). Finally, we decided to try $\mathrm{MgBr}_{2} \cdot \mathrm{Et}_{2} \mathrm{O}$, a completely different Lewis acid that has been recently used by Katayev's group in combination with pybox-type ligands in the trifluoromethylation of oxindoles. ${ }^{17}$ In our case we reached a $74 \%$ ee and a $76 \%$ yield.

Table 2. Optimization of the enantioselective pentafluoroethylation reaction.

\begin{tabular}{|c|c|c|c|c|c|c|}
\hline \multirow[b]{2}{*}{ Entry } & \multirow[b]{2}{*}{ Metal } & \multirow[b]{2}{*}{ Pybox } & \multicolumn{2}{|c|}{$\begin{array}{l}\mathrm{M}(\mathrm{OTf})_{3} / \text { pybox }(\mathrm{L}) \\
\mathrm{C}_{2} \mathrm{~F}_{5} \text { Source Reagent } \\
\text { Solvent, }-30^{\circ} \mathrm{C}, 4 \AA \mathrm{MS}\end{array}$} & \multirow[b]{2}{*}{ Yield $^{[a]}$} & \\
\hline & & & Solvent & Reagent & & $\begin{array}{l}e e^{[b]} \\
(\text { major } R)\end{array}$ \\
\hline 1 & $\mathrm{Eu}^{+3}$ & L1 & $\mathrm{MeCN}$ & 1 & $11 \%$ & $50 \%$ \\
\hline 2 & $\mathrm{Yb}^{+3}$ & L1 & $\mathrm{MeCN}$ & 1 & $76 \%$ & $45 \%$ \\
\hline 3 & $\mathrm{La}^{+3}$ & L1 & $\mathrm{MeCN}$ & 1 & $72 \%$ & $80 \%$ \\
\hline 4 & $\mathrm{La}^{+3}$ & L2 & $\mathrm{MeCN}$ & 1 & $36 \%$ & $10 \%$ \\
\hline 5 & $\mathrm{La}^{+3}$ & L3 & $\mathrm{MeCN}$ & 1 & $56 \%$ & $36 \%$ \\
\hline $6^{[c]}$ & $\mathrm{La}^{+3}$ & L1 & $\mathrm{CH}_{2} \mathrm{Cl}_{2}$ & 1 & $20 \%$ & $25 \%$ \\
\hline $7^{[d]}$ & $\mathrm{La}^{+3}$ & L1 & $\mathrm{MeCN}$ & 1 & $55 \%$ & $63 \%$ \\
\hline $8^{[e]}$ & $\mathrm{La}^{+3}$ & L1 & $\mathrm{MeCN}$ & 1 & $35 \%$ & $75 \%$ \\
\hline 9 & $\mathrm{La}^{3+}$ & L1 & $\mathrm{MeCN}$ & 2 & $60 \%$ & $72 \%$ \\
\hline 10 & $\mathrm{Eu}^{+3}$ & L1 & $\mathrm{MeCN}$ & 2 & $55 \%$ & $70 \%$ \\
\hline
\end{tabular}


${ }^{\text {[a] }}$ Yields of isolated pure compound 5d. ${ }^{[b]}$ Enantiomeric excesses determined by HPLC. ${ }^{[c]}$ Reaction done at -78 ․ C. ${ }^{[d]}$ Reaction done at room temperature. ${ }^{[e]}$ The reagent 1 was added dropwise with an automatic injector.

Next, we wanted to explore the scope of the reaction (Scheme 3). So, a range of cyclic $\beta$-keto esters were tested using the optimized pre-catalyst combination, La(OTf) 3 , L1 and hypervalent iodine(III)- $-\mathrm{CF}_{2} \mathrm{CF}_{3} \mathbf{1}$ in acetonitrile at $-30{ }^{\circ} \mathrm{C}$, under argon atmosphere and in presence of $4 \AA$ molecular sieves. The reaction was performed with a series of compounds derived from primary esters (4a-h). In general, the presence of electron-withdrawing groups in an aromatic position injures the ee's (5e-h, $50-80 \%$ ee). In contrary, those primary $\beta$-keto esters with no substituents or with electron-donating groups $(\mathrm{H}, \mathrm{OMe})$ in the aromatic positions gave around or over $80 \%$ ee. The presence of sterically bulky ${ }^{\mathrm{t}} \mathrm{Bu}$ and $\mathrm{CF}_{3}$ groups at sixth position (5b and $\mathbf{5 f}$ ) diminishes the ee independently of the electronic effects of the substituent. Once again, the effect of a bulkier ester is harmful for the enantiodifferentiation (5a vs $\mathbf{5 k}$ and $\mathbf{5} \mathbf{d}$ vs $\mathbf{5 j}$ ), as we have previously seen in our related previous work of trifluoromethylation. ${ }^{20}$

The assignment of the absolute configuration of compounds $\mathbf{5 a - k}$ was based on the comparison of the signal of their Cotton Effect (all compounds $\mathbf{5}$ present a negative Cotton effect, see $\mathrm{SI}$ ), as well as their negative specific rotation values. Both properties were consistent with the ones of the previosly prepared trifluoromethylated analogues..$^{9 a, 16 c, 20} \mathrm{We}$ assigned the absolute configuration $R$ to all compounds $\mathbf{5}$. 


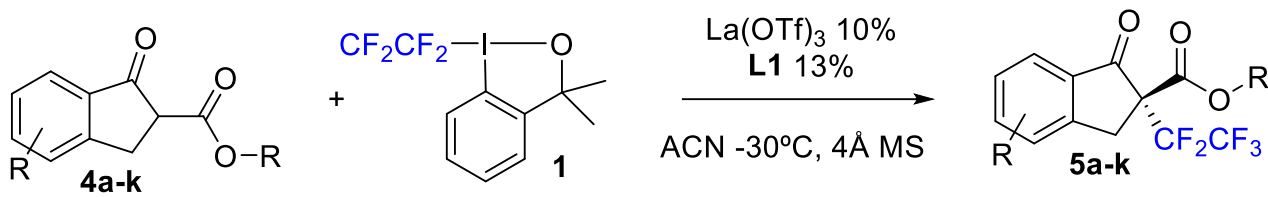<smiles>COC(=O)[C@]1(C(F)(F)F)Cc2ccccc2C1=O</smiles>

(R)-5a

$60 \%$ yield, $87 \%$ ee<smiles>COC(=O)C1(C(=O)OC)Cc2cc(OC)c(OC)cc2C1=O</smiles>

$72 \%$ yield, $80 \%$ ee<smiles>COC(=O)C1(C(=O)OC)Cc2c(F)cc(F)cc2C1=O</smiles>

$68 \%$ yield, $75 \%$ ee<smiles>[R16]c1ccc(C(C)(C)C)cc1C(=O)[C@]1(C(=O)OC)Cc2ccc(C(F)(F)F)cc2C1=O</smiles>

(R) $-5 \mathrm{~b}$

$78 \%$ yield, $63 \%$ ee<smiles>COC(=O)[C@]1(C(F)(F)F)Cc2ccc(F)cc2C1=O</smiles>

$72 \%$ yield, $60 \%$ ee<smiles>COC(=O)[C@]1(C(F)(F)F)Cc2cccc(Br)c2C1=O</smiles>

$71 \%$ yield, $80 \%$ ee<smiles>CC(C)(C)OC(=O)[C@]1(C(F)(F)F)Cc2ccccc2C1=O</smiles>

(R)-5k

$32 \%$ yield, $28 \%$ ee<smiles>COC(=O)C1(C(=O)OC)Cc2ccc(OC)cc2C1=O</smiles>

(R)-5c

$63 \%$ yield, $89 \%$ ee<smiles>COC(=O)[C@]1(C(F)(F)F)Cc2ccc(C(F)(F)F)cc2C1=O</smiles>

$63 \%$ yield, $50 \%$ ee<smiles>CCC(CC)OC(=O)[C@]1(C(=O)OC(C)(F)F)Cc2cc(OC)c(OC)cc2C1=O</smiles>

$47 \%$ yield, $30 \%$ ee

Scheme 3. Scope of the enantioselective $\alpha$-pentafluoroethylation of cyclic $\beta$-keto esters.

The activation of Togni type reagents have been previously studied by ${ }^{19} \mathrm{~F}$ NMR in different research groups including us. ${ }^{16 g, 17,20,24}$ In this work, we mixed 1 with $\mathrm{La}(\mathrm{OTf})_{3}$ (1:1) in deuterated acetonitrile. After 5 minutes, 1 was converted to a new species with a chemical shift of the $\mathrm{CF}_{3}$ from $\delta=-81.7$ to $\delta=-79.5 \mathrm{ppm}$ and a chemical shift of the $\mathrm{CF}_{2}$ from $\delta=-99.7$ to $\delta=-82.6 \mathrm{ppm}$. Thus, a very significant change was observed which indicates the coordination of 1 to lanthanide. Further ${ }^{19} \mathrm{~F}$ NMR-based titration furnished a Job plot indicating a 1:1 complexation of 1 with $\mathrm{La}(\mathrm{OTf})_{3}$ (Figure 3), in agreement with some examples in the literature. ${ }^{13 b, 20}$ Thus, we propose the formation of the cationic iodonium species 6 shown in Figure 3. 


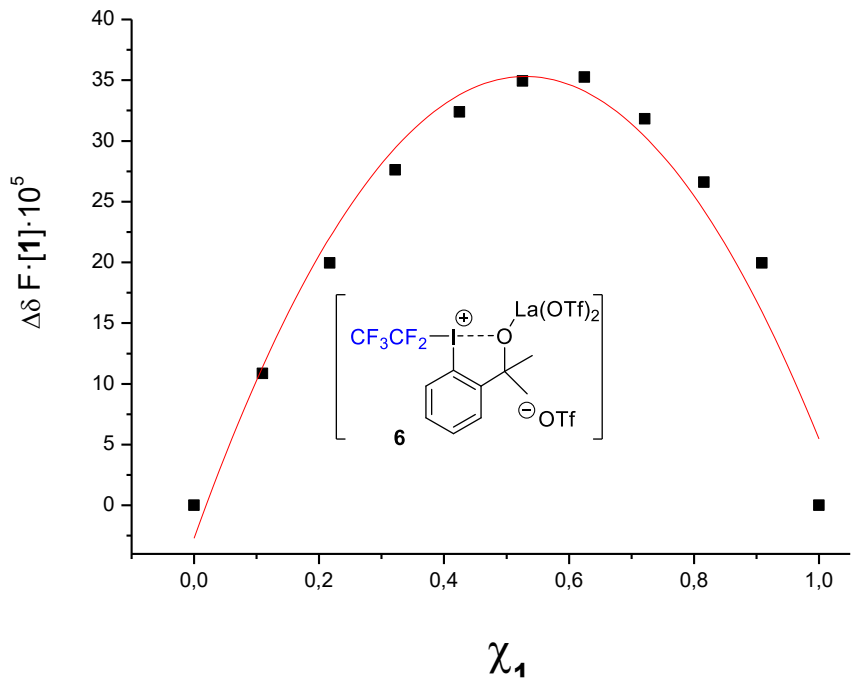

Figure 3. Job plot $\left(\mathbf{1}+\mathrm{La}(\mathrm{OTf})_{3}\right)$ by ${ }^{19} \mathrm{~F} \mathrm{NMR}\left(\mathrm{CD}_{3} \mathrm{CN}, 25^{\circ} \mathrm{C}, 400 \mathrm{MHz}\right)$ and the proposed cationic iodonium species 6 formation.

Next, the enantioselective catalytic reaction was tested in the presence of Galvinoxyl free radical, which is a classical radical scavenger. After 36 hours, the only products detected in the reaction of $\mathbf{4 d}$ and $\mathbf{1}$ were the starting material and the pentafluoroethylated Galvinoxyl $\mathbf{7}$ (Scheme 4). Thus, the presence of Galvinoxyl inhibits the pentafluoroethylation reaction. This new compound 7 was isolated in a 65\% yield and it was completely characterized by spectroscopic techniques, including HR-ESI-MS. The radical reaction pathway indicated by this result is in line with the known propensity of hypervalent iodine (III)- $\mathrm{CF}_{3}$ to generate $\mathrm{CF}_{3}$ radicals. ${ }^{13 b, 17,20,25}$

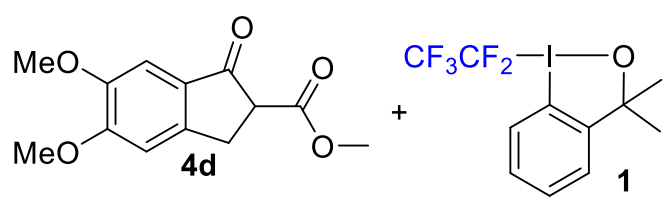

1

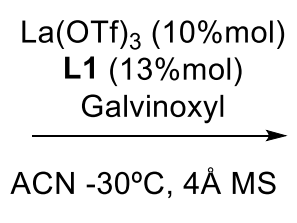<smiles>CC(C)(C)C1=CC(=Cc2cc(C(C)(C)C)c(OC(F)(F)F)c(C(C)(C)C)c2)C=C(C(C)(C)C)C1=O</smiles>

$65 \%$

Scheme 4. Pentafluoroethylation conducted in the presence of Galvinoxyl with formation of 7. 


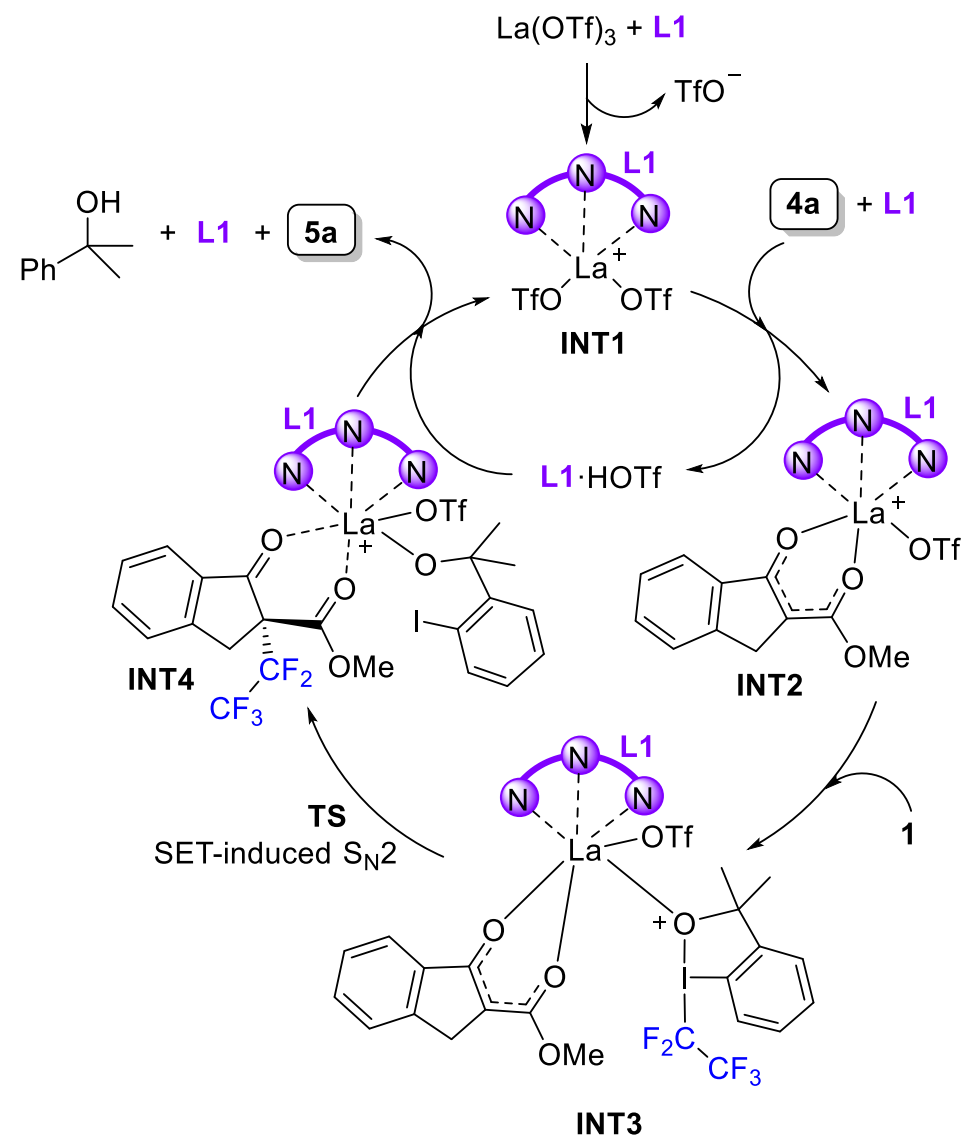

Scheme 5. Proposed catalytic cycle for the formation of $(\boldsymbol{R})-5 \mathrm{a}$ from $4 \mathrm{a}$ with La(OTf $)_{3}$, reagent 1 and the pybox ligand $\mathbf{L} \mathbf{1}$.

At the present stage we assume that the pentafluoroethylation step proceeds via a similar mechanistic scenario as we suggested in our recent work on the enantioselective $\alpha$ trifluoromethylation of cyclic $\beta$-keto esters. ${ }^{20}$ First, INT1 is formed by coordination of the pybox ligand to the metal by displacement of a OTf. Pybox ligand is the responsible for the abstraction of the $\alpha-\mathrm{H}$ in $\beta$-keto ester. Next, coordination of enolate-4a and reagent 1 to metal centre is produced to form INT2 and the subsequent coordination of reagent $\mathbf{1}$ is based on a complex 6, which formation has been demonstrated by this work by F NMR experiments (figure 3). Then, the coordination pattern of the $\beta$-keto ester $4 \mathbf{a}$ in INT3 reveals an efficient blockage of the prochiral Si face of the La(III) enolate. The hindrance of the Si face of this intermediate INT3 results in an efficient $\mathrm{S}_{N} 2$-like saddle point TS, which consists of a Re attack of the $\mathrm{C}_{\alpha}$ atom of the enolate moiety on the carbon atom of the $\mathrm{CF}_{2} \mathrm{CF}_{3}$ group in 1 , with concomitant departure of the iodine-aryl group. We propose a SET induced $\mathrm{S}_{\mathrm{N}} 2$-type pathway, thus leading the formation of $\mathrm{CF}_{3} \mathrm{CF}_{2}$ radicals that can explain the control of selectivity. In fact, hypervalent iodine (III)- $\mathrm{CF}_{3}$ reagent has been described as a precursor of electrophilic $\mathrm{CF}_{3}$ 
radical species. ${ }^{25}$ To date however, there exist only very few examples on their use in asymmetric trifluoromethylation. ${ }^{13 b}, 17,20$ This report is thereby the first example on the construction of enantioenriched pentafluoroethylated carbon centres using hypervalent iodine-based reagents proceeding through a SET pathway.

\section{Conclusions}

In summary, an efficient method for the enantioselective $\alpha$-pentafluoroethylation of alkyl 1-indanone-2-carboxylates is described. Racemic conditions were optimized using $\mathrm{Cs}_{2} \mathrm{CO}_{3}$ as base in acetonitrile. The enantioenriched pentafluorinated $\beta$-oxo esters were prepared using an hypervalent iodine(III)- $\mathrm{CF}_{2} \mathrm{CF}_{3}$ reagent and a lanthanide-pybox pre-catalyst to achieve good chemical yields and ee's (up to 89\%). The enantioselectivity of the reaction stems from the efficient blockage of one of the prochiral faces of the La(III) enolate by one unit of the C2symmetric ligand. We propose that the mechanism proceeds through a SET pathway involving $\mathrm{CF}_{2} \mathrm{CF}_{3}$ radicals.

\section{EXPERIMENTAL SECTION}

General information: The chemicals and solvents were purchased from Sigma-Aldrich or Fluorochem. Solvents were distilled and stored under argon in molecular sieves. IR spectra were determined either by transmission or by attenuated total reflectance mode (ATR). Enantiomeric excesses were determined, unless otherwise stated, by HPLC using a chiral column Daicel-AD-H. Optical rotations were measured with a Rudolph Autopol I polarimeter and they are reported as follows: $[\alpha]_{D}{ }^{r t}$ (c in g per $100 \mathrm{~mL}$, solvent). ${ }^{1} \mathrm{H}$ NMR spectra were recorded operating at 250,360 , and $400 \mathrm{MHz} .{ }^{13} \mathrm{C} \mathrm{NMR}$ spectra were registered at 63,91 , and $101 \mathrm{MHz} .{ }^{19} \mathrm{~F}$ NMR spectra were recorded decoupled to protons. Circular Dicroism were recorded in a spectropolarimeter J-715, JASCO, equipped with Peltier thermostat module. HRMS were recorded by a Bruker micrOTOF-QIl mass spectrometer (fly time analyzer) through positive electrospray ionization. Compounds $4\left(\mathbf{4 a},{ }^{20} \mathbf{4 b},{ }^{20} \mathbf{4 c},{ }^{20} \mathbf{4 d},{ }^{15} \mathbf{4 e},{ }^{20} \mathbf{4} \mathrm{f}^{20}, \mathbf{4 g},{ }^{20} \mathbf{4 h},{ }^{20}\right.$ were prepared as previously reported in our group. ${ }^{20}$ Compounds $4 \mathbf{i}^{19}{ }^{19} 4 \mathrm{k}^{19}$ and $\mathbf{4} \mathbf{l}^{19}$ were synthesized by a transesterification reaction from the corresponding methyl ester following a methodology adapted from a previously reported method of our group. ${ }^{22}$

Preparation of 3,3-dimethyl-1-( perfluoroethyl)-1,3-dihydro-1 $\lambda_{3}$-benzo[d][1,2]iodoxole (1): ${ }^{15}$ In flame dried Schlenk, $1.70 \mathrm{~g}$ (6.07 mmol, 1 equiv.) of 1-fluoro-3,3-dimethyl-1,3-dihydro- $1 \lambda_{3}$ - 
benzo[d][1,2]iodoxole were dissolved in $12 \mathrm{~mL}$ of dry acetonitrile, the solution was cooled down until $-20^{\circ} \mathrm{C}$. Then, $10 \mathrm{mg}(0.1$ equiv.) were added to the solution and $1.20 \mathrm{~mL}(6.07$ mmol) of $\mathrm{TMSCF}_{2} \mathrm{CF}_{3}$ were added carefully to the solution. The reaction was stirred for 12 hours under inert atmosphere. When the reaction was over, the solution was evaporated under high vacuum affording a beige solid. This crude was purified by flash column chromatography (hexane 9: ethyl acetate 1) yielding 1 in a 95\% yield $(2.19 \mathrm{~g}, 5.7 \mathrm{mmol}) .{ }^{1} \mathrm{H}$ NMR $\left(250 \mathrm{MHz},[\mathrm{D}] \mathrm{CDCl}_{3}, 25\right.$ 으, TMS): $\delta=1.51(\mathrm{~s}, 6 \mathrm{H}), 7.42(\mathrm{~m}, 2 \mathrm{H}), 7.56 \mathrm{ppm}(\mathrm{m}, 2 \mathrm{H}) ;{ }^{19} \mathrm{~F} \mathrm{NMR}$ (235 MHz, $\left.\mathrm{CDCl}_{3}\right) \delta(\mathrm{ppm}):-81.7$ (s, 3F), -99.7 ppm (s, 2F).

Preparation of 1-(perfluoroethyl)-1 $\lambda_{3}$-benzo[d][1,2]iodoxol-3(1H)-one (2): ${ }^{14}$ Step 1: In roundbottomed flask, $\mathrm{NaIO}_{4}(4.04 \mathrm{mmol})$ and 2-iodo benzoic acid $(4 \mathrm{mmol})$ were suspended in a mixture $\mathrm{AcOH} /$ water $(2.5 \mathrm{~mL}: 5.0 \mathrm{~mL})$ under air with vigorous stirring. The mixture was refluxed for $4 \mathrm{~h}$ and then diluted with $60 \mathrm{~mL}$ of cold water. After vigorous stirring for 10 minutes, the suspension was filtered and washed with iced water and cold acetone, respectively. The white solid was dried in a vacuum desiccation at 50 으, and it was identified as 1-hydroxy-1,2-benziodoxol-3-(1H)-one (94\% yield). ${ }^{1} \mathrm{H}$ NMR (250 MHz, [D]DMSO, 25으, TMS): $\delta=4.87$ (bs, $1 \mathrm{H}), 7.89\left(\mathrm{t},{ }^{3} J_{(H, H)}=7.3 \mathrm{~Hz}, 1 \mathrm{H}\right), 8.03(\mathrm{~m}, 1 \mathrm{H}), 8.14\left(\mathrm{dd},{ }^{3} J_{(H, H)}=7.3 \mathrm{~Hz},{ }^{4} J_{(H, H)}=\right.$ $1.4 \mathrm{~Hz}, 1 \mathrm{H}), 8.31 \mathrm{ppm}\left(\mathrm{d},{ }^{3} J_{(H, H)}=7.3 \mathrm{~Hz}, 1 \mathrm{H}\right)$. Step 2: In a round-bottomed flash, $4 \mathrm{mmol}$ of 1 hydroxy-1,2-benziodoxol-3-(1H)-one were dissolved in $4 \mathrm{~mL}$ of acetic anhydride, then the suspension was heated under reflux for 30 minutes. The mixture was cooled in a freezer overnight. The crystalized solid isolated from the organic phase and dried in a vacuum oven to provide the 1-acetoxy-1,2-benziodoxol-3-(1H)-one in a 95\% yield. ${ }^{1} \mathrm{H}$ NMR $\left(250 \mathrm{MHz},[\mathrm{D}] \mathrm{CDCl}_{3}\right.$, 25 으, TMS): $\delta=2.28(\mathrm{~s}, 3 \mathrm{H}), 7.74\left(\mathrm{t},{ }^{3} \mathrm{~J}_{(H, H)}=7.6 \mathrm{~Hz}, 1 \mathrm{H}\right), 7.99(\mathrm{~m}, 2 \mathrm{H}), 8.29 \mathrm{ppm}\left(\mathrm{d},{ }^{3} \mathrm{~J}_{(H, H)}=7.6\right.$ $\mathrm{Hz}, 1 \mathrm{H})$. Step 3: In a well dried Schlenk flash, $1 \mathrm{mmol}$ of 1-acetoxy-1,2-benziodoxol-3-(1H)-one were dissolved in a $5 \mathrm{~mL}$ of dry dichloromethane. Then, $2 \mathrm{mmol}$ of the Ruppert-Prakash reagent $\left(\mathrm{TMSCF}_{3}\right)$ were added carefully. Next, $1 \%$ mol of $\mathrm{KF}$ were added in one portion. After 2 hours stirring, the solvent was removed under high vacuum. The crude purified by flash column chromatography, yielding the titled compound 2 in a $60 \%$ yield. ${ }^{1} \mathrm{H} \mathrm{NMR}(400 \mathrm{MHz}$,

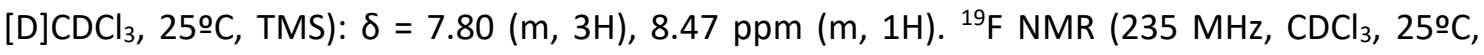
TMS): $\delta=-81.1(\mathrm{~s}, 3 \mathrm{~F}),-91.4 \mathrm{ppm}(\mathrm{s}, 2 \mathrm{~F})$.

Pentan-3-yl 5,6-dimethoxy-1-oxo-2-(perfluoroethyl)-2,3-dihydro-1H-indene-2-carboxy-late (4j): The methodology of preparation was adapted from a reported procedure: ${ }^{22}$ In a roundbottomed flask $0.50 \mathrm{~g}$ of $\mathbf{4 d}$ ( 1 eq.), $\mathrm{ZnO}$ (0.2 eq.) and the corresponding alcohol (10 equivalents) were dissolved in toluene. The reaction mixture was heated up to $140^{\circ} \mathrm{C}$, under a distillation setup, until total conversion was observed by TLC ( 8 hours). Then, the reaction 
mixture was filtered through Celite ${ }^{\bullet}$ and the solvent was removed under reduced pressure. The product obtained was purified by column chromatography on silica-gel (hexane: ethyl acetate $=10: 1$ ) obtaining $0.51 \mathrm{~g}$ of $4 \mathbf{j}$ (84\% yield). ${ }^{1} \mathrm{H} \mathrm{NMR} \mathrm{(400} \mathrm{MHz},[\mathrm{D}] \mathrm{CDCl}_{3}, 25$ 으, $\left.\mathrm{TMS}\right): \delta=$ $0.84(\mathrm{~m}, 6 \mathrm{H}), 1.53(\mathrm{~m}, 4 \mathrm{H}), 3.23\left(\mathrm{dd},{ }^{3} J_{(H, H)}=7.2 \mathrm{~Hz},{ }^{2} J_{(H, H)}=18.0 \mathrm{~Hz}, 1 \mathrm{H}\right), 3.39\left(\mathrm{dd},{ }^{3} J_{(H, H)}=3.6\right.$, $\left.{ }^{2} J_{(H, H)}=18.0 \mathrm{~Hz}, 1 \mathrm{H}\right), 3.65\left(\mathrm{dd},{ }^{3} J_{(H, H)}=3.6 \mathrm{~Hz},{ }^{3} J_{(H, H)}=7.2 \mathrm{~Hz}, 1 \mathrm{H}\right), 3.84(\mathrm{~s}, 3 \mathrm{H}), 3.92(\mathrm{~s}, 3 \mathrm{H}), 4.85$ (quint, $\left.{ }^{3} J_{(H, H)}=7.2 \mathrm{~Hz}, 1 \mathrm{H}\right), 6.87(\mathrm{~s}, 1 \mathrm{H}), 7.11 \mathrm{ppm}(\mathrm{s}, 1 \mathrm{H}) .{ }^{13} \mathrm{C}\left[{ }^{1} \mathrm{H}\right] \mathrm{NMR}\left(101 \mathrm{MHz},[\mathrm{D}] \mathrm{CDCl}_{3}\right.$, 25 으, TMS): $\delta=9.5,9.6,26.5,26.5,30.1,53.8,56.0,56.3,78.2,104.7,107.2,127.9,149.2$, 149.6, 155.9, 169.3, 198.2 ppm. IR (ATR): 2967, 1731, 1591, 1313, 1194, $1021 \mathrm{~cm}^{-1}$. HR-MS (ESI) $\mathrm{m} / \mathrm{z}:[\mathrm{M}+\mathrm{Na}]^{+}$Calcd for $\mathrm{C}_{17} \mathrm{H}_{22} \mathrm{O}_{5} \mathrm{Na} 349.0270$; found 349.0264.

\section{General procedure for the enantioselective electrophilic $\alpha$-pentafluoroethylation of alkyl 1-}

indanone-2-carboxylates: In a $10 \mathrm{ml}$ dried Schlenk flask in presence of $4 \AA \AA$ molecular sieves, $\mathrm{La}(\mathrm{OTf})_{3}$ (0.10 eq.) and the ligand $(S, R)$-indanyl-pybox (0.13 eq.) were dissolved in dry acetonitrile $(3 \mathrm{ml})$. The colourless reaction mixture was left stirring at room temperature under inert atmosphere overnight. Next, the corresponding $\beta$-keto ester ( $80 \mathrm{mg} ; 1$ eq.) was added to the reaction mixture and it was left stirring at room temperature for 30 minutes. Then, the reaction mixture was cooled down until $-35{ }^{\circ} \mathrm{C}$ and, once at this temperature, the pentafluoroethylating agent (1.3 eq.) was added to the mixture in one portion. The reaction mixture was left at this temperature under argon atmosphere until complete conversion of the reagent observed by TLC. Afterwards, the solvent was removed under reduced pressure and the product was purified by column chromatography on silica gel.

Methyl (R)-1-oxo-2-(perfluoroethyl)-2,3-dihydro-1H-indene-2-carboxylate (5a): ${ }^{16}$ According to the general procedure, $77 \mathrm{mg}(0.25 \mathrm{mmol})$ of $5 \mathrm{a}$ were synthesized from $80 \mathrm{mg}$ of starting material $(60 \%$ yield) as colourless oil after purification on silica gel (hexane: ethyl acetate $=$ 2:1). ${ }^{1} \mathrm{H}$ NMR (400 MHz, [D]CDCl 3,25 o C, TMS): $\delta=3.62\left(\mathrm{~d}^{2}{ }^{2} \mathrm{~J}_{(H, H)}=17.7 \mathrm{~Hz}, 1 \mathrm{H}\right), 3.82(\mathrm{~s}, 3 \mathrm{H})$, $3.93\left(d,{ }^{2} J_{(H, H)}=17.7 \mathrm{~Hz}, 1 \mathrm{H}\right), 7.47\left(\mathrm{t},{ }^{3} J_{(H, H)}=7.5 \mathrm{~Hz}, 1 \mathrm{H}\right), 7.55\left(\mathrm{~d},{ }^{3} J_{(H, H)}=7.5 \mathrm{~Hz}, 1 \mathrm{H}\right), 7.71(\mathrm{td}$, $\left.{ }^{3} J_{(H, H)}=7.5 \mathrm{~Hz},{ }^{4} J_{(H, H)}=1.2 \mathrm{~Hz}, 1 \mathrm{H}\right), 7.85 \mathrm{ppm}\left(\mathrm{d},{ }^{3} J_{(H, H)}=7.5 \mathrm{~Hz}, 1 \mathrm{H}\right) ;{ }^{19} \mathrm{~F} \mathrm{NMR}\left(376 \mathrm{MHz}, \mathrm{CDCl}_{3}\right.$, $25 \circ \mathrm{C}, \mathrm{TMS}): \delta=-79.6(\mathrm{~s}, 3 \mathrm{~F}),-115.0\left(\mathrm{~d},{ }^{2} J_{(F, F)}=278.0 \mathrm{~Hz}, 1 \mathrm{~F}\right),-116.8 \mathrm{ppm}\left(\mathrm{d},{ }^{2} J_{(F, F)}=278.0 \mathrm{~Hz}\right.$, $1 \mathrm{~F}) ;[\alpha]_{\mathrm{D}}^{20}=-21.9\left(\mathrm{c}=0.0032\right.$ in MeCN), 87\% ee (absolute configuration $R$ ). HPLC: $\mathrm{t}_{\mathrm{r}}(R)=11.14$ min and $t_{r}(S)=18.34$ min, Daicel Chiralpack $A D-H$ column $(0.46 \mathrm{~cm} \phi \times 25 \mathrm{~cm})$ with hexane:'PrOH (99.5:0.5) as non-stationary phase and $1.0 \mathrm{~mL} \cdot \mathrm{min}^{-1}$.

Methyl (R)-6-(tert-butyl)-1-oxo-2-(perfluoroethyl)-2,3-dihydro-1H-indene-2-carboxylate (5b): According to the general procedure, $86 \mathrm{mg}(0.24 \mathrm{mmol})$ of $\mathbf{5 b}$ were synthesized from $75 \mathrm{mg}$ of starting material $(78 \%$ yield) as colourless oil after purification on silica gel (hexane: 
dichloromethane $=2: 1) .{ }^{1} \mathrm{H}$ NMR $\left(360 \mathrm{MHz},[\mathrm{D}] \mathrm{CDCl}_{3}, 25\right.$ 知, TMS): $\delta=1.36(\mathrm{~s}, 9 \mathrm{H}), 3.57$ (d, $\left.{ }^{2} J_{(H, H)}=17.5 \mathrm{~Hz}, 1 \mathrm{H}\right), 3.83(\mathrm{~s}, 3 \mathrm{H}), 3.87\left(\mathrm{~d},{ }^{2} J_{(H, H)}=17.5 \mathrm{~Hz}, 1 \mathrm{H}\right), 7.47\left(\mathrm{~d},{ }^{3} J_{(H, H)}=7.8 \mathrm{~Hz}, 1 \mathrm{H}\right), 7.57$ $\left(\mathrm{d},{ }^{3} \mathrm{~J}_{(\mathrm{H}, H)}=7.8 \mathrm{~Hz}, 1 \mathrm{H}\right), 7.82 \mathrm{ppm}(\mathrm{bs}, 1 \mathrm{H}) ;{ }^{19} \mathrm{~F} \mathrm{NMR}\left(235 \mathrm{MHz}, \mathrm{CDCl}_{3}, 25 \mathrm{O} \mathrm{C}, \mathrm{TMS}\right): \delta=-79.5$ (s, $3 F),-114.9\left(d,{ }^{2} J_{(F, F)}=278.1 \mathrm{~Hz}, 1 F\right),-116.6 \mathrm{ppm}\left(\mathrm{d},{ }^{2} J_{(F, F)}=278.1 \mathrm{~Hz}, 1 \mathrm{~F}\right) \cdot{ }^{13} \mathrm{C}\left[{ }^{1} \mathrm{H}\right] \mathrm{NMR}(101 \mathrm{MHz}$, [D]CDCl 3,25 ㄷ C, TMS): $\delta=31.2,33.0$ (bs), 53.8, 62.7 (dd, ${ }^{2} J_{(C, F)}=22.2 \mathrm{~Hz},{ }^{2} J_{(C, F)}=18.2 \mathrm{~Hz}$ ), 77.2, $115.5(\mathrm{~m}), 120.0(\mathrm{~m}), 121.7,125.7,133.9,134.4,149.0,152.2,165.0\left(\mathrm{~d}, 3_{(C, F)}=6.8 \mathrm{~Hz}\right), 192.4$ ppm. IR (ATR): 2961, 1785, 1730, 1435, 1191, $1072 \mathrm{~cm}^{-1}$. HR-MS (ESI) m/z: [M+Na] Calcd for $\mathrm{C}_{17} \mathrm{H}_{17} \mathrm{~F}_{5} \mathrm{O}_{3} \mathrm{Na}$ 387.0990; found 387.0986. $[\alpha]_{D}^{20}=-12.6$ ( $\mathrm{c}=0.0039$ in $\mathrm{MeCN}$ ), 63\% ee (absolute configuration $R$ ). HPLC: $\mathrm{t}_{\mathrm{r}}(R)=6.37 \mathrm{~min}$ and $\mathrm{t}_{\mathrm{r}}(S)=6.93 \mathrm{~min}$, Daicel Chiralpack $\mathrm{AD}-\mathrm{H}$ column $(0.46 \mathrm{~cm} \phi \times 25 \mathrm{~cm})$ with hexane: $\mathrm{PrOH}(99.5: 0.5)$ as non-stationary phase and $1.0 \mathrm{~mL} \cdot \mathrm{min}^{-1}$.

Methyl (R)-6-methoxy-1-oxo-2-(perfluoroethyl)-2,3-dihydro-1H-indene-2-carboxylate (5c): According to the general procedure, $110 \mathrm{mg}$ of $5 \mathrm{c}$ were synthesized from $100 \mathrm{mg}$ of starting material $(84 \%$ yield) as colourless oil after purification on silica gel (hexane: ethyl acetate $=$ 2:1). ${ }^{1} \mathrm{H}$ NMR (250 MHz, [D]CDCl $\left., 25 \stackrel{\circ}{ } \mathrm{C}, \mathrm{TMS}\right): \delta=3.53\left(\mathrm{~d},{ }^{2} J_{(H, H)}=18.0 \mathrm{~Hz}, 1 \mathrm{H}\right), 3.81(\mathrm{~m}, 7 \mathrm{H})$, $7.23\left(\mathrm{~d},{ }^{4} J_{(H, H)}=2.3 \mathrm{~Hz}, 1 \mathrm{H}\right), 7.27\left(\mathrm{dd},{ }^{3} J_{(H, H)}=8.4 \mathrm{~Hz},{ }^{4} J_{(H, H)}=2.3 \mathrm{~Hz}, 1 \mathrm{H}\right), 7.41 \mathrm{ppm}\left(\mathrm{d},{ }^{3} J_{(H, H)}=8.4\right.$ $\mathrm{Hz}, 1 \mathrm{H}) .{ }^{19} \mathrm{~F} \mathrm{NMR}\left(235 \mathrm{MHz}, \mathrm{CDCl}_{3}, 25\right.$ 으, TMS): $\delta=-79.5(\mathrm{~s}, 3 \mathrm{~F}),-114.9\left(\mathrm{~d},{ }^{2} \mathrm{~J}_{(F, F)}=278.8 \mathrm{~Hz}, 1 \mathrm{~F}\right),-$ $116.5 \mathrm{ppm}\left(\mathrm{d},{ }^{2} \mathrm{~J}_{(F, F)}=278.8 \mathrm{~Hz}, 1 \mathrm{~F}\right) \cdot{ }^{13} \mathrm{C}\left[{ }^{1} \mathrm{H}\right] \mathrm{NMR}\left(101 \mathrm{MHz},[\mathrm{D}] \mathrm{CDCl}_{3}, 25{ }^{\circ} \mathrm{C}, \mathrm{TMS}\right): \delta=32.8$ (bs), 53.9, 55.7, $62.9\left(\mathrm{dd},{ }^{2} J_{(C, F)}=22.3 \mathrm{~Hz},{ }^{2} J_{(C, F)}=18.2 \mathrm{~Hz}\right), 106.2,112.8(\mathrm{~m}), 127.7(\mathrm{~m}), 126.1,126.9$, 135.2, 144.5, 160.1, $165.0\left(\mathrm{~d},{ }^{3} J_{(C, F)}=6.7 \mathrm{~Hz}\right), 192.2 \mathrm{ppm}$. IR (ATR): 2924, 1725, 1495, 1434, 1194, $1026 \mathrm{~cm}^{-1}$. HR-MS (ESI) m/z: [M+Na] $]^{+}$Calcd for $\mathrm{C}_{14} \mathrm{H}_{11} \mathrm{~F}_{5} \mathrm{O}_{4} \mathrm{Na}$ 361.0470; found 361.0467; $[\alpha]_{D}{ }^{20}=-10.0\left(\mathrm{c}=0.0027\right.$ in MeCN), 85\% ee (absolute configuration $R$ ). HPLC: $\mathrm{t}_{\mathrm{r}}(R)=8.59 \mathrm{~min}$ and $\mathrm{t}_{\mathrm{r}}(S)=10.58 \mathrm{~min}$, Daicel Chiralpack AD-H column $(0.46 \mathrm{~cm} \phi \times 25 \mathrm{~cm})$ with hexane: ${ }^{i} \mathrm{PrOH}$ (99.5:0.5) as non-stationary phase and $1.0 \mathrm{~mL} \cdot \mathrm{min}^{-1}$.

Methyl (R)-5,6-dimethoxy-1-oxo-2-(perfluoroethyl)-2,3-dihydro-1H-indene-2-carboxylate (5d): ${ }^{15}$ According to the general procedure, $84 \mathrm{mg}(0.23 \mathrm{mmol})$ of $5 \mathrm{~d}$ were synthesized from $80 \mathrm{mg}$ of starting material ( $72 \%$ yield) as colourless solid after purification on silica gel (hexane: ethyl acetate $=2: 1) .{ }^{1} \mathrm{H}$ NMR $\left(250 \mathrm{MHz},[\mathrm{D}] \mathrm{CDCl}_{3}, 25 \mathrm{O} \mathrm{C}, \mathrm{TMS}\right): \delta=3.51\left(\mathrm{~d},{ }^{2} \mathrm{~J}_{(H, H)}=17.6 \mathrm{~Hz}, 1 \mathrm{H}\right), 3.82$ $(\mathrm{m}, 4 \mathrm{H}), 3.94(\mathrm{~s}, 3 \mathrm{H}), 4.02(\mathrm{~s}, 3 \mathrm{H}), 6.93(\mathrm{~s}, 1 \mathrm{H}), 7.21 \mathrm{ppm}(\mathrm{s}, 1 \mathrm{H}),{ }^{19} \mathrm{~F} \mathrm{NMR}\left(235 \mathrm{MHz}, \mathrm{CDCl}_{3}\right) \delta$ (ppm): -79.5 (s, 3F), -114.9 (d, $\left.{ }^{2} J_{(F, F)}=279.7 \mathrm{~Hz}, 1 F\right),-117.5 \mathrm{ppm}\left(\mathrm{d},{ }^{2} J_{(F, F)}=279.7 \mathrm{~Hz}, 1 \mathrm{~F}\right) ;[\alpha]_{D}{ }^{20}=$ -14.0 ( $\mathrm{c}=0.0032$ in MeCN), 80\% ee (absolute configuration $R$ ). HPLC: $\operatorname{ta}_{r}(R)=44.36$ min and $\operatorname{ta}_{r}(S)$ $=54.47 \mathrm{~min}$, Daicel Chiralpack AD-H column $(0.46 \mathrm{~cm} \phi \times 25 \mathrm{~cm})$ with hexane: ${ }^{i} \operatorname{PrOH}(99: 1)$ as non-stationary phase and $1.0 \mathrm{~mL} \cdot \mathrm{min}^{-1}$. 
According to the general procedure, $90 \mathrm{mg}(0.28 \mathrm{mmol})$ of $5 \mathrm{e}$ were synthesized from $80 \mathrm{mg}$ of starting material $(72 \%$ yield) as colourless oil after purification on silica gel (hexane: dichloromethane $=7: 3) .{ }^{1} \mathrm{H} \mathrm{NMR}\left(400 \mathrm{MHz},[\mathrm{D}] \mathrm{CDCl}_{3}, 25 \mathrm{O} C, \mathrm{TMS}\right): \delta=3.59\left(\mathrm{~d},{ }^{2} \mathrm{~J}_{(H, H)}=17.5 \mathrm{~Hz}\right.$, $1 \mathrm{H}), 3.82(\mathrm{~s}, 3 \mathrm{H}), 3.89\left(\mathrm{~d},{ }^{2} J_{(H, H)}=17.5 \mathrm{~Hz}, 1 \mathrm{H}\right), 7.45(\mathrm{~m}, 2 \mathrm{H}), 7.53 \mathrm{ppm}\left(\mathrm{dd},{ }^{3} J_{(H, F)}=8.3 \mathrm{~Hz},{ }^{4} J_{(H, H)}=\right.$ $2.1 \mathrm{~Hz}, 1 \mathrm{H}) .{ }^{19} \mathrm{~F}$ NMR $\left(235 \mathrm{MHz}, \mathrm{CDCl}_{3}, 25 \circ \mathrm{C}, \mathrm{TMS}\right): \delta=-78.6(\mathrm{~s}, 3 \mathrm{~F}),-112.9(\mathrm{~s}, 1 \mathrm{~F}),-114.8$ (d, $\left.{ }^{2} J_{(F, F)}=278.5 \mathrm{~Hz}, 1 \mathrm{~F}\right),-116.6 \mathrm{ppm}\left(\mathrm{d},{ }^{2} J_{(F, F)}=278.5 \mathrm{~Hz}, 1 \mathrm{~F}\right) .{ }^{13} \mathrm{C}\left[{ }^{1} \mathrm{H}\right] \mathrm{NMR}\left(91 \mathrm{MHz},[\mathrm{D}] \mathrm{CDCl}_{3}, 25\right.$ 的, TMS): $\delta=32.9\left(\mathrm{~d},{ }^{3} J_{(C, F)}=3.2 \mathrm{~Hz}\right), 54.0,63.1\left(\mathrm{dd},{ }^{2} J_{(C, F)}=22.2 \mathrm{~Hz},{ }^{2} J_{(C, F)}=18.2 \mathrm{~Hz}\right), 111.2\left(\mathrm{~d},{ }^{2} J_{(C, F)}\right.$ $=22.5 \mathrm{~Hz}), 112.2(\mathrm{~m}), 117.6(\mathrm{~m}), 124.2\left(\mathrm{~d},{ }^{2} J_{(C, F)}=24.0 \mathrm{~Hz}\right), 127.7\left(\mathrm{~d},{ }^{3} J_{(C, F)}=8.1 \mathrm{~Hz}\right), 135.7(\mathrm{~d}$, $\left.{ }^{3} J_{(C, F)}=8.1 \mathrm{~Hz}\right), 146.9\left(\mathrm{~d},{ }^{4} J_{(C, F)}=2.2 \mathrm{~Hz}\right), 161.5,164.0,164.5\left(\mathrm{~d},{ }^{3} J_{(C, F)}=7.1 \mathrm{~Hz}\right), 191.2 \mathrm{ppm} . \mathrm{IR}$ (ATR): 2921, 1751, 1721, 1614, 1296, $1149 \mathrm{~cm}^{-1}$. HR-MS (ESI) m/z: [M+Na] Calcd for $\mathrm{C}_{13} \mathrm{H}_{8} \mathrm{~F}_{6} \mathrm{O}_{3} \mathrm{Na}$ 349.0270; found 349.0264. $[\alpha]_{D}{ }^{20}=-19.7$ ( $\mathrm{c}=0.0036$ in $\mathrm{MeCN}$ ), 60\% ee (absolute configuration $R$ ). HPLC: $\mathrm{t}_{r}(R)=7.34 \mathrm{~min}$ and $\mathrm{t}_{r}(S)=8.01 \mathrm{~min}$, Daicel Chiralpack AD-H column $(0.46 \mathrm{~cm} \phi \times 25 \mathrm{~cm})$ with hexane:'PrOH (99:1) as non-stationary phase and $1.0 \mathrm{~mL} \cdot \mathrm{min}^{-1}$.

Methyl (R)-6-(trifluoromethyl)-1-oxo-2-(perfluoroethyl)-2,3-dihydro-1H-indene-2-carboxylate (5f): According to the general procedure, $71 \mathrm{mg}(0.16 \mathrm{mmol})$ of $\mathbf{5 f}$ were synthesized from 80 $\mathrm{mg}$ of starting material (63\% yield) as colourless oil after purification on silica gel (hexane:

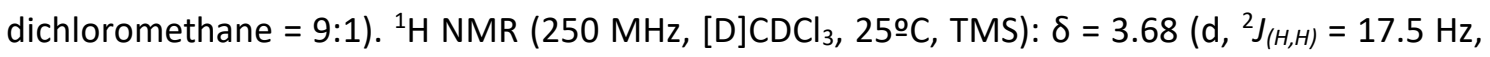
$1 \mathrm{H}), 3.83(\mathrm{~s}, 3 \mathrm{H}), 4.01\left(\mathrm{~d},{ }^{2} J_{(H, H)}=17.5 \mathrm{~Hz}, 1 \mathrm{H}\right), 7.70\left(\mathrm{~d},{ }^{3} J_{(H, H)}=8.1 \mathrm{~Hz}, 1 \mathrm{H}\right), 7.95\left(\mathrm{dd},{ }^{3} J_{(H, H)}=8.1\right.$ $\left.\mathrm{Hz},{ }^{4} J_{(H, H)}=1.7 \mathrm{~Hz}, 1 \mathrm{H}\right), 8.11 \mathrm{ppm}\left(\mathrm{d},{ }^{4} J_{(H, H)}=1.7 \mathrm{~Hz}, 1 \mathrm{H}\right) .{ }^{19} \mathrm{~F} \mathrm{NMR}\left(235 \mathrm{MHz}, \mathrm{CDCl}_{3}, 25 \mathrm{O} C, \mathrm{TMS}\right)$ : $\delta=-63.2(\mathrm{~s}, 3 \mathrm{~F}),-79.6(\mathrm{~s}, 3 \mathrm{~F}),-114.7\left(\mathrm{~d},{ }^{2} J_{(F, F)}=278.7 \mathrm{~Hz}, 1 \mathrm{~F}\right),-116.7 \mathrm{ppm}\left(\mathrm{d},{ }^{2} J_{(F, F)}=278.7 \mathrm{~Hz}\right.$, 1F). ${ }^{13} \mathrm{C}\left[{ }^{1} \mathrm{H}\right] \mathrm{NMR}\left(91 \mathrm{MHz},[D] C D C l_{3}, 25\right.$ oC, $\left.\mathrm{TMS}\right): \delta=33.5(\mathrm{~m}), 54.2,62.6\left(\mathrm{dd},{ }^{2} J_{(C, F)}=22.2 \mathrm{~Hz}\right.$, $\left.{ }^{2} J_{(C, F)}=18.8 \mathrm{~Hz}\right), 112.2(\mathrm{~m}), 117.6(\mathrm{~m}), 122.7\left(\mathrm{q},{ }^{3} J_{(C, F)}=3.9 \mathrm{~Hz}\right), 123.3\left(\mathrm{q},{ }^{1} J_{(C, F)}=273.1 \mathrm{~Hz}\right), 127.1$, $131.5\left(q,{ }^{2} J_{(C, F)}=32.7 \mathrm{~Hz}\right), 132.7\left(\mathrm{~d},{ }^{3} J_{(C, F)}=3.9 \mathrm{~Hz}\right), 134.3,154.5,164.2\left(\mathrm{~d},{ }^{3} J_{(C, F)}=7.1 \mathrm{~Hz}\right), 191.0$ ppm. IR (ATR): 2922, 1751, 1722, 1614, 1257, 1150. $\mathrm{cm}^{-1}$. HR-MS (ESI) m/z: [M+Na] Calcd for $\mathrm{C}_{14} \mathrm{H}_{8} \mathrm{~F}_{8} \mathrm{O}_{3} \mathrm{Na}$ 399.0238; found 399.0229. $[\alpha]_{D}{ }^{20}=-8.6(\mathrm{c}=0.0022$ in $\mathrm{MeCN}$ ), $50 \%$ ee (absolute configuration $R$ ). HPLC: $\mathrm{t}_{\mathrm{r}}(R)=6.04 \mathrm{~min}$ and $\mathrm{t}_{\mathrm{r}}(S)=6.82 \mathrm{~min}$, Daicel Chiralpack AD-H column $(0.46 \mathrm{~cm} \phi \times 25 \mathrm{~cm})$ with hexane: $\operatorname{PrOH}(99.5: 0.5)$ as non-stationary phase and $1.0 \mathrm{~mL} \cdot \mathrm{min}^{-1}$.

Methyl (R)-5,7-difluoro-1-oxo-2-(perfluoroethyl)-2,3-dihydro-1H-indene-2-carboxylate (5g): According to the general procedure, $73 \mathrm{mg}(0.21 \mathrm{mmol})$ of $5 \mathrm{~g}$ were synthesized from $70 \mathrm{mg}$ of starting material (68\% yield) as a colourless oil after purification on silica gel (hexane: dichloromethane $=1: 1) .{ }^{1} \mathrm{H} N M R\left(400 \mathrm{MHz},[\mathrm{D}] \mathrm{CDCl}_{3}, 25 \mathrm{O} C, \mathrm{TMS}\right): \delta=3.59\left(\mathrm{~d},{ }^{2} \mathrm{~J}_{(\mathrm{H}, H)}=18.1 \mathrm{~Hz}\right.$, $1 \mathrm{H}), 3.85(\mathrm{~s}, 3 \mathrm{H}), 3.94\left(\mathrm{dd},{ }^{2} J_{(H, H)}=18.1 \mathrm{~Hz}, 1 \mathrm{H}\right), 6.85\left(\mathrm{td},{ }^{3} J_{(H, F)}=9.0 \mathrm{~Hz},{ }^{4} J_{(H, H)}=1.2 \mathrm{~Hz}, 1 \mathrm{H}\right), 7.04$ $\operatorname{ppm}\left(\mathrm{d},{ }^{3} J_{(H, F)}=7.6 \mathrm{~Hz},{ }^{4} J_{(H, H)}=1.2 \mathrm{~Hz}, 1 \mathrm{H}\right) .{ }^{19} \mathrm{~F} \mathrm{NMR}\left(235 \mathrm{MHz}, \mathrm{CDCl}_{3}, 25 \mathrm{O} C, \mathrm{TMS}\right): \delta=-79.6(\mathrm{~s}$, 
3F), $-95.1\left(d,{ }^{4} J_{(F, F)}=14.8 \mathrm{~Hz}, 1 F\right),-107.1\left(d,{ }^{4} J_{(F, F)}=14.8 \mathrm{~Hz}, 1 F\right),-114.9\left(d,{ }^{2} J_{(F, F)}=279.5 \mathrm{~Hz}, 1 F\right),-$

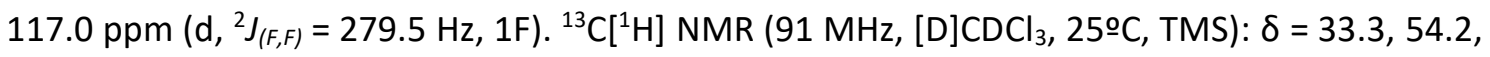
$62.9\left(\mathrm{dd},{ }^{2} J_{(C, F)}=22.0 \mathrm{~Hz},{ }^{2} J_{(C, F)}=18.5 \mathrm{~Hz}\right), 104.9\left(\mathrm{dd},{ }^{3} J_{(C, F)}=27.0 \mathrm{~Hz},{ }^{3} J_{(C, F)}=23.1 \mathrm{~Hz}\right), 109.5(\mathrm{dd}$, $\left.{ }^{3} J_{(C, F)}=23.1 \mathrm{~Hz},{ }^{3} J_{(C, F)}=4.3 \mathrm{~Hz}\right), 113.4(\mathrm{~m}), 116.8(\mathrm{~m}), 125.3(\mathrm{~m}), 143.3,155.1\left(\mathrm{dd},{ }^{3} J_{(C, F)}=12.3 \mathrm{~Hz}\right.$, $\left.{ }^{4} J_{(C, F)}=3.1 \mathrm{~Hz}\right), 160.5\left(\mathrm{dd},{ }^{1} J_{(C, F)}=270.4 \mathrm{~Hz},{ }^{3} J_{(C, F)}=14.2 \mathrm{~Hz}\right), 164.2\left(\mathrm{~d},{ }^{3} J_{(C, F)}=11.1 \mathrm{~Hz}\right), 168.8(\mathrm{dd}$, $\left.{ }^{1} J_{(C, F)}=270.4 \mathrm{~Hz},{ }^{3} J_{(C, F)}=14.2 \mathrm{~Hz}\right), 186.5 \mathrm{ppm}$. IR (ATR): 2968, 1751, 1721, 1622, 1495, $1258 \mathrm{~cm}^{-1}$. HR-MS (ESI) m/z: [M+Na] $]^{+}$Calcd for $\mathrm{C}_{13} \mathrm{H}_{7} \mathrm{~F}_{7} \mathrm{O}_{3} \mathrm{Na}$ 367.0176; found 367.0176. $[\alpha]_{\mathrm{D}}{ }^{20}=-16.3$ (c = 0.0032 in $\mathrm{MeCN}$ ), 75\% ee (absolute configuration $R$ ). HPLC: $\mathrm{t}_{r}(R)=9.96$ min and $\mathrm{t}_{r}(S)=13.48$ min, Daicel Chiralpack AD-H column $(0.46 \mathrm{~cm} \phi \times 25 \mathrm{~cm})$ with hexane:'PrOH (99.5:0.5) as nonstationary phase and $1.0 \mathrm{~mL} \cdot \mathrm{min}^{-1}$.

Methyl (R)-7-bromo-1-oxo-2-(perfluoroethyl)-2,3-dihydro-1H-indene-2-carboxylate

(5h): According to the general procedure, $81 \mathrm{mg}(0.21 \mathrm{mmol})$ of $5 \mathrm{~h}$ were synthesized from $80 \mathrm{mg}$ of starting material ( $71 \%$ yield) as a colourless oil after purification on silica gel (hexane: dichloromethane $=6: 4) .{ }^{1} \mathrm{H} \mathrm{NMR}\left(400 \mathrm{MHz},[\mathrm{D}] \mathrm{CDCl}_{3}, 25\right.$ 으, TMS): $\delta=3.56\left(\mathrm{~d},{ }^{2} J_{(H, H)}=17.6 \mathrm{~Hz}\right.$, $1 \mathrm{H}), 3.83(\mathrm{~s}, 3 \mathrm{H}), 3.89\left(\mathrm{~d},{ }^{2} J_{(H, H)}=17.6 \mathrm{~Hz}, 1 \mathrm{H}\right), 7.50(\mathrm{~m}, 2 \mathrm{H}), 7.84 \mathrm{ppm}\left(\mathrm{dd},{ }^{3} J_{(H, F)}=7.1 \mathrm{~Hz},{ }^{4} J_{(H, H)}=\right.$ $1.3 \mathrm{~Hz}, 1 \mathrm{H}) .{ }^{19} \mathrm{~F} \mathrm{NMR}\left(376 \mathrm{MHz}, \mathrm{CDCl}_{3}, 25\right.$ 知, TMS): $\delta=-79.1(\mathrm{~s}, 3 \mathrm{~F}),-1145\left(\mathrm{~d},{ }^{2} \mathrm{~J}_{(F, F)}=279.1 \mathrm{~Hz}\right.$, 1F), $-116.4 \mathrm{ppm}\left(\mathrm{d},{ }^{2} J_{(F, F)}=279.1 \mathrm{~Hz}, 1 \mathrm{~F}\right) .{ }^{13} \mathrm{C}\left[{ }^{1} \mathrm{H}\right] \mathrm{NMR}\left(101 \mathrm{MHz},[\mathrm{D}] \mathrm{CDCl}_{3}, 25 \mathrm{O} C, \mathrm{TMS}\right): \delta=32.4$ (bs), 54.1, $63.9\left(\mathrm{dd},{ }^{2} J_{(C, F)}=22.0 \mathrm{~Hz},{ }^{2} J_{(C, F)}=18.5 \mathrm{~Hz}\right), 112.5(\mathrm{~m}), 117.5(\mathrm{~m}), 125.1,131.5,133.7$, 136.5, 154.1, $164.5\left(\mathrm{~d},{ }^{3} \mathrm{~J}_{(C, F)}=7.3 \mathrm{~Hz}\right), 189.2 \mathrm{ppm}$. IR (ATR): 2961, 1758, 1722, 1618, $1284 \mathrm{~cm}^{-1}$. HR-MS (ESI) m/z: [M+Na] ${ }^{+}$Calcd for $\mathrm{C}_{13} \mathrm{H}_{8} \mathrm{BrF}_{5} \mathrm{O}_{3} \mathrm{Na}$ 408.9469; found 408.9463. [ $\left.\alpha\right]_{\mathrm{D}}{ }^{20}=-14.3$ (c $=0.0031$ in MeCN), 80\% ee (absolute configuration $R$ ). HPLC: $\mathrm{t}_{\mathrm{r}}(R)=13.58 \mathrm{~min}$ and $\mathrm{t}_{\mathrm{r}}(S)=19.80$ min, Daicel Chiralpack AD-H column $(0.46 \mathrm{~cm} \phi \times 25 \mathrm{~cm})$ with hexane:'PrOH (99.5:0.5) as nonstationary phase and $1.0 \mathrm{~mL} \cdot \mathrm{min}^{-1}$.

Pentan-3-yl 1-oxo-2-(perfluoroethyl)-2,3-dihydro-1H-indene-2-carboxylate (5i): According to the general procedure, $99 \mathrm{mg}(0.28 \mathrm{mmol})$ of $5 \mathbf{i}$ were synthesized from $100 \mathrm{mg}$ of starting material (68\% yield) as a colourless oil after purification on silica gel (hexane: dichloromethane $=9: 1) .{ }^{1} \mathrm{H} N M R\left(360 \mathrm{MHz},[\mathrm{D}] \mathrm{CDCl}_{3}, 25{ }^{\circ} \mathrm{C}, \mathrm{TMS}\right): \delta=0.83(\mathrm{~m}, 6 \mathrm{H}), 1.58(\mathrm{~m}, 4 \mathrm{H}), 3.61\left(\mathrm{~d},{ }^{2} J_{(H, H)}=\right.$ $17.5 \mathrm{~Hz}, 1 \mathrm{H}$ ), $3.88\left(\mathrm{~d},{ }^{2} J_{(H, H)}=17.5 \mathrm{~Hz}, 1 \mathrm{H}\right), 4.83$ (quint, $\left.{ }^{3} J_{(H, H)}=7.2 \mathrm{~Hz}, 1 \mathrm{H}\right), 7.46\left(\mathrm{t},{ }^{3} J_{(H, H)}=7.5 \mathrm{~Hz}\right.$, $1 \mathrm{H}), 7.54\left(\mathrm{~d},{ }^{3} J_{(H, H)}=7.5 \mathrm{~Hz}, 1 \mathrm{H}\right), 7.69\left(\mathrm{td},{ }^{3} J_{(H, H)}=7.5 \mathrm{~Hz},{ }^{4} J_{(H, H)}=1.2 \mathrm{~Hz}, 1 \mathrm{H}\right), 7.83 \mathrm{ppm}\left(\mathrm{d},{ }^{3} J_{(H, H)}=\right.$ $7.5 \mathrm{~Hz}, 1 \mathrm{H}) .{ }^{19} \mathrm{~F}$ NMR $\left(235 \mathrm{MHz}, \mathrm{CDCl}_{3}, 25 \circ \mathrm{O}, \mathrm{TMS}\right): \delta=-78.8(\mathrm{~s}, 3 \mathrm{~F}),-114.0\left(\mathrm{~d},{ }^{2} \mathrm{~J}_{(F, F)}=279.4 \mathrm{~Hz}\right.$, 1F), $-115.0 \mathrm{ppm}\left(\mathrm{d},{ }^{2} J_{(F, F)}=279.4 \mathrm{~Hz}, 1 \mathrm{~F}\right) .{ }^{13} \mathrm{C}\left[{ }^{1} \mathrm{H}\right] \mathrm{NMR}\left(400 \mathrm{MHz},[D] C D C C_{3}, 25 \circ C, T M S\right): \delta=9.1$, 26.0, $33.6\left(\mathrm{~d},{ }^{3} J_{(C, F)}=2.6 \mathrm{~Hz}\right), 62.7\left(\mathrm{dd},{ }^{2} J_{(C, F)}=22.5 \mathrm{~Hz},{ }^{2} J_{(C, F)}=18.6 \mathrm{~Hz}\right), 80.5,113.0(\mathrm{~m}), 118.1$ (m), 125.3, 126.1, 128.4, 134.2, 136.1, 151.4, $164.2\left(\mathrm{~d},{ }^{3} \mathrm{~J}_{(C, F)}=11.1 \mathrm{~Hz}\right), 192.5 \mathrm{ppm}$. IR (ATR): 
2924 1721, 1607, 1464, 1274, 1185. HR-MS (ESI) m/z: $[\mathrm{M}+\mathrm{Na}]^{+}$Calcd for $\mathrm{C}_{17} \mathrm{H}_{17} \mathrm{~F}_{5} \mathrm{O}_{3} \mathrm{Na}$ 387.0990; found 387.0994.

Pentan-3-yl (R)-5,6-dimethoxy-1-oxo-2-(perfluoroethyl)-2,3-dihydro-1H-indene-2-carboxylate (5j): According to the general procedure, $45 \mathrm{mg}(0.11 \mathrm{mmol})$ of $5 \mathbf{j}$ were synthesized from 70 mg of starting material ( $47 \%$ yield) as transparent oil after purification on silica gel (hexane: dichloromethane $=9: 1) .{ }^{1} \mathrm{H}$ NMR $\left(250 \mathrm{MHz},[\mathrm{D}] \mathrm{CDCl}_{3}, 25\right.$ 으, TMS): $\delta=0.87(\mathrm{~m}, 6 \mathrm{H}), 1.61(\mathrm{~m}$, $4 \mathrm{H}), 3.50\left(\mathrm{~d},{ }^{2} \mathrm{~J}_{(H, H)}=17.3 \mathrm{~Hz}, 1 \mathrm{H}\right), 3.78\left(\mathrm{~d},{ }^{2} \mathrm{~J}_{(H, H)}=17.3 \mathrm{~Hz}, 1 \mathrm{H}\right), 3.94(\mathrm{~s}, 3 \mathrm{H}), 4.02(\mathrm{~s}, 3 \mathrm{H}), 4.85$ (quint, $\left.{ }^{3} J_{(H, H)}=6.9 \mathrm{~Hz}, 1 \mathrm{H}\right), 6.93(\mathrm{~s}, 1 \mathrm{H}), 7.21 \mathrm{ppm}(\mathrm{s}, 1 \mathrm{H}) .{ }^{19} \mathrm{~F} \mathrm{NMR}\left(235 \mathrm{MHz}, \mathrm{CDCl}_{3}, 25\right.$ 으, TMS): $\delta=-78.6(\mathrm{~s}, 3 \mathrm{~F}),-114.2\left(\mathrm{~d},{ }^{2} J_{(F, F)}=278.9 \mathrm{~Hz}, 1 \mathrm{~F}\right),-115.4 \mathrm{ppm}\left(\mathrm{d},{ }^{2} J_{(F, F)}=278.9 \mathrm{~Hz}, 1 \mathrm{~F}\right) .{ }^{13} \mathrm{C}\left[{ }^{1} \mathrm{H}\right]$ NMR (101 MHz, [D]CDCl $, 25 \circ C, T M S): \delta=9.3,26.0,33.2(\mathrm{~m}), 56.2,56.4,62.9\left(\mathrm{dd},{ }^{2} J_{(C, F)}=22.0\right.$ $\left.\mathrm{Hz},{ }^{2} J_{(C, F)}=18.5 \mathrm{~Hz}\right), 80.3,105.3,106.9,112.0(\mathrm{~m}), 117.5(\mathrm{~m}), 127.0,143.3,147.3,150.2,164.6$ $\left(d, 3^{3} J_{(C, F)}=7.0 \mathrm{~Hz}\right), 190.9$ ppm. IR (ATR): 2971, 1762, 1714, 1592, 1504, $1201 \mathrm{~cm}^{-1}$. HR-MS (ESI) $\mathrm{m} / \mathrm{z}:[\mathrm{M}+\mathrm{Na}]^{+}$Calcd for $\mathrm{C}_{19} \mathrm{H}_{21} \mathrm{~F}_{5} \mathrm{O}_{5} \mathrm{Na}$ 447.1201; found 447.1198. $[\alpha]_{\mathrm{D}}^{20}=-6.1$ (c=0.0040 in MeCN), 30\% ee (absolute configuration $R$ ). HPLC: $\operatorname{tr}_{r}(S)=7.19 \mathrm{~min}$ and $\operatorname{tr}_{\mathrm{r}}(R)=7.81 \mathrm{~min}$, Daicel Chiralpack AD-H column $(0.46 \mathrm{~cm} \phi \times 25 \mathrm{~cm})$ with hexane: ${ }^{i} \mathrm{PrOH}(99.5: 0.5)$ as non-stationary phase and $1.0 \mathrm{~mL} \cdot \mathrm{min}^{-1}$.

Tert-butyl (R)-1-oxo-2-(perfluoroethyl)-2,3-dihydro-1H-indene-2-carboxylate (5k): ${ }^{16}$ According to the general procedure, $28 \mathrm{mg}$ of $\mathbf{5 k}$ were synthesized from $60 \mathrm{mg}(0.25 \mathrm{mmol})$ of starting material ( $32 \%$ yield) as colourless oil after purification on silica gel (hexane: ethyl acetate $=$ 9:1). ${ }^{1} \mathrm{H}$ NMR (250 MHz, [D]CDCl 3,25 o C, TMS): $\delta=1.45$ (s, 9H), $3.56\left(\mathrm{~d},{ }^{2} J_{(H, H)}=17.7 \mathrm{~Hz}, 1 \mathrm{H}\right)$, $3.85\left(\mathrm{~d},{ }^{2} J_{(H, H)}=17.7 \mathrm{~Hz}, 1 \mathrm{H}\right), 7.45\left(\mathrm{t},{ }^{3} J_{(H, H)}=7.5 \mathrm{~Hz}, 1 \mathrm{H}\right), 7.53\left(\mathrm{~d},{ }^{3} J_{(H, H)}=7.5 \mathrm{~Hz}, 1 \mathrm{H}\right), 7.68(\mathrm{td}$, $\left.{ }^{3} J_{(H, H)}=7.5 \mathrm{~Hz},{ }^{4} J_{(H, H)}=1.2 \mathrm{~Hz}, 1 \mathrm{H}\right), 7.83 \mathrm{ppm}\left(\mathrm{d},{ }^{3} J_{(H, H)}=7.5 \mathrm{~Hz}, 1 \mathrm{H}\right) .{ }^{19} \mathrm{~F}$ NMR $\left(235 \mathrm{MHz}, \mathrm{CDCl}_{3}\right.$, $25 \circ C, T M S): \delta=-78.6(s, 3 F),-113.6\left(d,{ }^{2} J_{(F, F)}=278.3 \mathrm{~Hz}, 1 F\right),-115.6 \mathrm{ppm}\left(\mathrm{d},{ }^{2} J_{(F, F)}=278.3 \mathrm{~Hz}, 1 \mathrm{~F}\right)$. $[\alpha]_{\mathrm{D}}{ }^{20}=-6.8(\mathrm{c}=0.0033$ in $\mathrm{MeCN}), 28 \%$ ee (absolute configuration $R$ ).

Adamantyl 1-oxo-2-(perfluoroethyl)-2,3-dihydro-1H-indene-2-carboxylate (5I): According to the general procedure, $107 \mathrm{mg}(0.25 \mathrm{mmol})$ of $\mathbf{5 l}$ were synthesized from $110 \mathrm{mg}$ of starting material (71\% yield) as a transparent liquid after purification on silica gel (hexane: ethyl acetate $=9: 1) .{ }^{1} \mathrm{H}$ NMR $\left(250 \mathrm{MHz},[\mathrm{D}] \mathrm{CDCl}_{3}, 25 \circ \mathrm{O}, \mathrm{TMS}\right): \delta=1.64$ (bs, 6H), 2.08 (bs, 6H), 2.16 (bs, 3H), $3.55\left(\mathrm{~d},{ }^{2} J_{(H, H)}=17.6 \mathrm{~Hz}, 1 \mathrm{H}\right), 3.84\left(\mathrm{~d},{ }^{2} J_{(H, H)}=17.6 \mathrm{~Hz}, 1 \mathrm{H}\right), 7.48(\mathrm{~m}, 2 \mathrm{H}), 7.68\left(\mathrm{t},{ }^{3} J_{(H, H)}=\right.$ $7.5 \mathrm{~Hz}, 1 \mathrm{H}), 7.83 \mathrm{ppm}\left(\mathrm{t},{ }^{3} J_{(H, H)}=7.5 \mathrm{~Hz}, 1 \mathrm{H}\right) .{ }^{19} \mathrm{~F} \mathrm{NMR}\left(235 \mathrm{MHz}, \mathrm{CDCl}_{3}, 25 \circ \mathrm{O}, \mathrm{TMS}\right): \delta=--78.5$ $(\mathrm{s}, 3 F),-113.6\left(\mathrm{~d},{ }^{2} J_{(F, F)}=279.9 \mathrm{~Hz}, 1 \mathrm{~F}\right),-115.60 \mathrm{ppm}\left(\mathrm{d},{ }^{2} J_{(F, F)}=279.9 \mathrm{~Hz}, 1 F\right) \cdot{ }^{13} \mathrm{C}\left[{ }^{1} \mathrm{H}\right] \mathrm{NMR}(101$ $\mathrm{MHz},[\mathrm{D}] \mathrm{CDCl}_{3}, 25$ ㅇ $\left.\mathrm{C}, \mathrm{TMS}\right): \delta=30.9,33.6$ (bs), $35.940 .8,63.2\left(\mathrm{dd},{ }^{2} J_{(C, F)}=22.2 \mathrm{~Hz},{ }^{2} J_{(C, F)}=18.3\right.$ $\mathrm{Hz}), 84.7,112.7(\mathrm{~m}), 118.6(\mathrm{~m}), 125.3,126.1,128.3,134.2,136.0,151.6,162.6\left(\mathrm{~d},{ }^{3} J_{(C, F)}=10.9\right.$ 
Hz), 192.8 ppm. IR (ATR): 2914, 2853, 1752, 1725, 1607, 1457, $1204 \mathrm{~cm}^{-1}$. HR-MS (ESI) m/z: $[\mathrm{M}+\mathrm{Na}]^{+}$Calcd for $\mathrm{C}_{22} \mathrm{H}_{21} \mathrm{~F}_{5} \mathrm{O}_{3} \mathrm{Na}$ 451.1303; found 451.1296.

2,6-Di-tert-butyl-4-(3,5-di-tert-butyl-4-(pentafluoroethoxy)benzylidene)cyclohexa-2,5-dien-1one (7): ${ }^{1} \mathrm{H} \mathrm{NMR}\left(250 \mathrm{MHz},[\mathrm{D}] \mathrm{CDCl}_{3}, 25 \mathrm{o} \mathrm{C}, \mathrm{TMS}\right): \delta=1.30$ (bs, 36H), 6.59 (bs, 3H), $6.84 \mathrm{ppm}$ (bs, 2H). ${ }^{19} \mathrm{~F}$ NMR (235 MHz, CDCl 3,25 으, TMS): $\delta=-77.8$ (s, 3F), -117.1 ppm (s, 2F). ${ }^{13} \mathrm{C}\left[{ }^{1} \mathrm{H}\right]$ NMR (63 MHz, [D]CDCl 3 25으, TMS): $\delta=29.3,29.6,35.0,35.6,115.2(\mathrm{~m}), 121.2(\mathrm{~m}), 124.3$, 133.5, 134.8, 135.5, 150.5, 186.3 ppm. HR-MS (ESI) m/z: [M+H] ${ }^{+}$Calcd for $\mathrm{C}_{31} \mathrm{H}_{41} \mathrm{~F}_{5} \mathrm{O}_{2}$ 563.2919; found 563.2911 .

\section{Associated content}

The Supporting Information includes the ${ }^{1} \mathrm{H}$ NMR, ${ }^{13} \mathrm{C}$ NMR, ${ }^{19} \mathrm{~F}$ NMR spectra and ESI and HPLC chromatograms.

\section{Author Information}

*E-mail: albert.granados@uab.es

*Email: adelina.vallribera@uab.es

ORCID

Albert Granados: 0000-0002-5362-5966

Adelina Vallribera: 0000-0002-6452-4589

\section{Acknowledgments}

We are thankful for financial support from Spain's MICINN (RTI2018-097853-B-I00) and MEC (CTQ2016-81797-REDC, RED2018-102387-T). Funding from DURSI-Generalitat de Catalunya (2017-SGR465). UAB is also acknowledged by A.G. for his postdoctoral contract.

\section{References}

(1) (a) Smart, B. E. Fluorine Substituent Effects (on Bioactivity). J. Fluorine Chem. 2001, 109, 3-11. (b) Ismail, F. M. D. Important Fluorinated Drugs in Experimental and Clinical Use. J. Fluorine Chem. 2002, 118, 27-33. (c) Isanbor, C.; O'Hagan D. Fluorine in Medicinal Chemistry: A Review of Anti-cancer Agents. J. Fluorine Chem. 2006, 127, 303-319. (d) Müller, K.; Faeh, C.;. 
Diederich, F. Fluorine in Pharmaceuticals: Looking Beyond Intuition. Science 2007, 317, 1881-1886. (e) Purser, S.; Moore, P. R.; Swallow, S.; Gouverneur, V. Fluorine in Medicinal Chemistry. Chem. Soc. Rev. 2008, 37, 320-330. (f) Fluorine in Medicinal Chemistry and Chemical Biology, I. Ojima, Ed.; Wiley-Blackwell: Hobpken, NY 2009. (g) O’Hagan, D.; Fluorine in Health Care: Organofluorine Containing Blockbuster drugs, J. Fluorine Chem. 2010, 131, 1071-1081. (h) Ilardi, E. A.; Vitaku, E.; Njardarson, J. T. Data-Mining for Sulfur and Fluorine: An Evaluation of Pharmaceuticals to Reveal Opportunities for Drug Design and Discovery. J. Med. Chem. 2014, 57, 2832-2842. (i) Orsi, D. L.; Altman, R. A. Exploiting the Unusual Effects of Fluorine in Methodology. Chem. Commun. 2017, 53, 7168-7181.

(2) Liang, T.; Neumann, C. N.; Ritter, T. Introduction of Fluorine and Fluorine-Containing Functional Groups. Angew. Chem. Int. Ed. 2013, 52, 8214-8264.

(3) (a) Landelle, G.; Panossian, A.; Pazenok, S.; Vors, J.-P.; Leroux, F. R. Recent Advances in Transition Metal-Catalyzed Csp²-Monofluoro-, Difluoro-, Perfluoromethylation and Trifluoromethylthiolation. Beilstein J. Org. Chem. 2013, 9, 2476-2536. (b) Mestre, J.; Castillón, S.; Boutureira, O. "Ligandless"Pentafluoroethylation of Unactivated (Hetero)aryl andAlkenyl Halides Enabled by the Controlled Self-Condensation of $\mathrm{TMSCF}_{3}-$ Derived $\mathrm{CuCF}_{3}$. J. Org. Chem. 2019, 84, 15087-15097. (c) Pertusati, F.; Serpi, M.; Pileggi, E. Polyfluorinated Scaffolds in Drug Discovery in : Fluorine in Life Sciences: Pharmaceuticals, Medicinal Diagnostics and Agrochemicals, Academic Press 2019, 141-180.

(4) Park, B. K.; Kitteringham, N. R.; O'Neil P. M. Metabolism of Fluorine-Containing Drugs. Annu. Res. Pharmacol. Toxicol. 2001, 41, 443-470.

(5) Wang, J.; Sánchez-Rosello, M.; Aceña, J.-L.; del Pozo, C.; Sorochinsky, A. E. Fustero, S.; Soloshonok, V. A.; Liu, H. Fluorine in Pharmaceutical Industry: Fluorine-Containing Drugs Introduced to the Market in the Last Decade (2001-2011). Chem. Rev. 2014, 114, 2432-2506.

(6) Poliakov, A.; Sandtröm, A.; Akerblom, E.; Danielson, U. H. Mechanistic Studies of Electrophilic Protease Inhibitors of Full Length Hepatic C Virus (HCV) NS3. J. Enzym. Inhib. Med. Ch. 2007, 22, 191-199.

(7) Kokotos, G.; Hsu, Y.-H.; Burke, J. E.; Baskakis, C.; Kokotos, C. G.; Magrioti, V.; Dennis, E. A. Potent and Selective Fluoroketone Inhibitors of Group VIA Calcium-Independent Phospholipase A2. J. Med.Chem. 2010, 53, 3602-3610.

(8) Pertusati, F.; Ferla, S.; Bassetto, M.; Brancale, A.; Khandil, S.; Westwell, A. D.; McGuigan, C. A new series of Bicalutamide, Enzalutamide and Enobosarmderivatives carrying 
Pentafluorosulfanyl (SF5) and Pentafluoroethyl $\left(\mathrm{C}_{2} \mathrm{~F}_{5}\right)$ Substituents: Improved Antiproliferative Agents Against Prostate Cancer. Eur. J. Med. Chem. 2019, 180, 14-19.

(9) (a) Ma, J.-A; Cahard, D. Mild Electrophilic Trifluoromethylation of $\beta$-Ketoesters and Silyl Enol Ethers with 5-Trifluoroethyldibenzothiophenium Tetrafluoroborate. J. Org. Chem. 2003, 68, 8726-8729. (b) Kieltsch, I.; Eisenberger, P.; Togni, A. Mild Electrophilic Trifluoromethylation of Carbon- and Sulfur- Centered Nucleophiles by a Hypervalent lodine(III)-CF 3 reagent. Angew. Chem. Int. Ed. 2007, 46, 754-757. (c) Ma, J.-A.; Cahard, D. Strategies for Nucleophilic, Electrophilic and Radical Trifluoromethylations. J. Fluorine Chem. 2007, 128, 975-996. (d) Matsnev, A.; Noritake, S.; Nomura, Y.; Tokunaga, E.; Nakamura, S.; Shibata, N. Efficient Access to Extended Yagupolskii-Umemoto Type Reagents: Triflic Acid Catalyzed Intramolecular Cyclization of Ortho-ethynylaryltrifluoromethylsufanes. Angew. Chem. Int. Ed. 2010, 49, $572-$ 576. (e) Furuya, T.; Kamlet, A. S.; Ritter, T. Catalysis for Fluorination and Trifluoromethylation. Nature, 2011, 473, 470-477. (f) Ohtsuka, Y.; Uraguchi, D.; Yamamoto, K.; Yamakawa, T. Synthesis of 2-(Trifluoromethyl)-1,3-dicarbonyl Compounds through Direct Trifluoromethylation with $\mathrm{CF}_{3} \mathrm{l}$ and their Application to Fluorinated Pyrazoles. Tetrahedron $2012,68,2636-2649$.

(10) (a) Zeng, Y.; Hu, J.-B. Silver-Catalyzed Formal Insertion of Arynes into Rf-I Bonds. Chem. Eur. J. 2014, 20, 6866. (b) Sladojevich, F.; McNeill, E.; Börgel, J.; Zheng, S.-L.; Ritter, T. Condensed-phase Halogen-bonded $\mathrm{CF}_{3} \mathrm{I}$ and $\mathrm{C}_{2} \mathrm{~F}_{5}$ I Adducts for Perfluoroalkylation Reactions. Angew. Chem. Int. Ed. 2015, 54, 3712.

(11) (a) Yaguposkii, L. M.; Maletina, I. I.; Kondratenko, N. V.; Orda, V. V. A New Method of Perfluoroalkylation. Synthesis 1978, 835-837.

(12) Umemoto, T.; Kuriu, Y.; Shuyama, H.; Miyano, O.; Nakayama, S.-I. Syntheses and Properties of (Perfluoroalkyl)phenyliodonium triflates (Fits Reagents) and their Analogues. J. Fluorine Chem. 1986, 31, 37-56.

(13) (a) Lin, Q.-Y.; Xu, X.-H.; Qing, F.-L. Chemo-, Regio-, and Stereoselective Trifluoromethylation of Styrenes via Visible Light-Driven Single-Electron Transfer (SET) and Triplet-Triplet Energy Transfer (TTET) Processes. J. Org. Chem. 2014, 79, 10434. (b) D. Katayev, H. Kajita, A. Togni, Magnesium-Catalyzed Electrophilic Trifluoromethylation: Facile Access to All-Carbon Quaternary Centers in Oxindoles. Chem. Eur. J. 2017, 23, 8353-8357.

(14) (a) Studer, A. 6-Trifluoromethyl-Phenanthridines through Radical Trifluoromethylation of Isonitriles. Angew. Chem. Int. Ed. 2013, 52, 10792-10795. (b) Mizuta, S.; Engle, K.; Verhoog, 
S.; Wheelhouse, K.; Rassias, G.; Tompson, A. L.; Gouverneur, V. Trifluoromethylation of Allylsilanes under Photoredox Catalysis. Org. Lett. 2013, 15, 1250-1253. (c) Carboni, A.; Dagousset, G.; Magnier, E.; Masson, G. Photoredox-Induced Three-Component Oxy-', Amino-', and Carbotrifluoromethylation of Enecarbamates. Org. Lett. 2014, 16, 1240-1243.

(15) Zhu, J.; Li, Y.; Ni, C.; Shen, Q. Pentafluoroethylbenziodoxole $\left(B I X-C_{2} F_{5}\right)$ : A Shelf-Stable Reagent for Pentafluoroethylation of $\beta$-Keto esters and Arylboronic acids. Chin. J. Chem. 2016, $34,662-668$.

(16) (a) Umemoto, T.; Adachi, K. New Method for Trifluoromethylation of Enolate Anions and Applications to Regio-diastero- and Enantioselective Trifluoromethylation. J. Org. Chem. 1994, 59, 5692-5699. (b) Nagib, D. A.; Scott, M. E.; MacMillan, D. W. C. Enantioselective $\alpha-$ Trifluoromethylation of Aldehydes via Photoredox Organocatalysis. J. Am. Chem. Soc. 2009, 131, 10875-10877. (c) Noritake, S.; Shibata, N.; Nomura, Y.; Huang, Y.; Matnev, A.; Nakamura, S.; Toru,T.; Cahard, D. Enantioselective Electrophilic Trifluoromethylation of $\beta$-keto esters with Umemoto Reagents Induced by Chiral Nonracemic Guanidines. Org. Biomol. Chem. 2009, 7, 3599-3604. (d) Shibata, N.; Matsnev, A.; Cahard D. Shelf-stable Electrophilic Trifluoromethylating Reagents: a Brief Historical Perspective. Beilstein J. Org. Chem. 2010, 6, 119. (e) Allen, A. E.; MacMillan D. W. C. The productive Merger of lodonium Salts and Organocatalysis: a Non-Photolytic Approach to the Enantioselective $\alpha$-Trifluoromethylation of Aldehydes. J. Am. Chem. Soc. 2010, 132, 4986-4987. (f) Deng, Q. -H.; Wadepohl, H.; Gade, L. H Highly Enantioselective Copper-Catalyzed Electrophilic Trifluoromethylation of $\beta$-Ketoesters. J. Am. Chem. Soc. 2012, 134, 10769-10772. (g) Barata-Vallejo, S.; Lantaño, B.; Postigo, A. Recent Advances in Trifluoromethylation Reactions with Electrophilic Trifluoromethylating Reagents. Chem. Eur. J. 2014, 20, 16806-16829.(h) Yang, X.; Wu, T.; Phipps, R. J.; Toste, F. D. Advances in Catalytic Enantioselective Fluorination, Mono- $\mathrm{Di}$ and Trifluoromethylation and Trifluoromethylthiolation Reaction., Chem. Rev. 2015, 115, 826-870. (i) Charpentier, J.; Früh, N.; Togni, A. Electrophilic Trifluoromethylation by use of Hypervalent lodine Reagents. Chem. Rev. 2015, 115, 650-682. (j) Miró, J.; del Pozo, C. Fluorine and Gold: a Fruitful Partnership. Chem Rev. 2016, 116, 11924-11966.

(17) Calvo, R.; Comas-Vives, A.; Togni, A.; Katayev, D. Taming Radical Intermediates for the Construction of Enantioenriched Trifluoromethylated Quaternary Carbon Centers. Angew. Int. Chem. Ed. 2019, 58, 1447-1452.

(18) (a) Comelles, J.; Pericas, A.; Moreno-Mañas, M.; Vallribera, A.; Drudis-Solé, G.;Lledós, A.; Parella, T.; Roglans, A.; García-Granda, S.; Roces-Fernández, L. Highly Enantioselective 
Electrophilic Amination and Michael Addition of Cyclic $\beta$-Ketoesters Induced by Lanthanides and (S,S)-ip-pybox: The Mechanism. J. Org. Chem. 2007, 72, 2077-2087. (b) Pericas, A.; Shafir, A.; Vallribera, A. Asymmetric Synthesis of L-Carbidopa Based on a Highly Enantioselective $\alpha$ Amination. Org. Lett. 2013, 15, 1448-1451. Highlighted in Synfacts 2013, 9, 700. (c) Pericas, A.; Jiménez, R.; Granados, A.; Shafir, A.; Vallribera, A.; Roglans, A.; Molins, E. Lanthanides-pybox: An Excellent Combination for Highly Enantioselective Electrophilic $\alpha$-Amination of Acyclic $\beta$-Keto Esters. Isolation of Ternary Pybox/Ln/ $\beta$-Keto Ester Complexes. ChemistrySelect. 2016, 1 , 4305-4312. (d) Granados, A.; del Olmo, A.; Peccati, P.; Billard, T.; Sodupe, M.; Vallribera, A. Fluorous L-Carbidopa Precursors: Highly Enantioselective Synthesis and Computational Prediction of Bioactivity. J. Org. Chem. 2018, 83, 303-313.

(19) Granados, A.; Sarró, P.; Vallribera, A. Catalytic Asymmetric Fluorination of Alkyl 1indanone-2-carboxylates Ruled by Pybox-Eu(III) Combination. Molecules, 2019, 24, 1141-1151.

(20) Granados, A.; Rivilla, I.; Cossío, F. P.; Vallribera, A. Lanthanum-Catalyzed Enantioselective Trifluoromethylation by Using an Electrophilic Hypervalent lodine Reagent. Chem. Eur. J. 2019, 25, 8214-8218.

(21) Li, Y.; Studer, A. Transition-Metal-Free Trifluoromethylaminoxylation of Alkenes. Angew. Int. Chem. Ed. 2012, 51, 8221-8224.

(22) Pericas, A.; Shafir, A.; Vallribera, A. Zinc(II) Oxide: an Efficient Catalyst for Selective Transesterification of $\beta$-Ketoesters. Tetrahedron 2008, 64, 9258-9263. Highlighted in Synfacts, 2009, 1, 81.

(23) Matoušek, V.; Václavík, J.; Hájek, P.; Charpentier, J.; Blastik, Z. E.; Pietrasiak, E.; Budinská, A.; Togni, A. ; Beier, P. Expanding the Scope of Hypervalent lodine Reagents for Perfluoroalkylation: From Trifluoromethyl to Functionalized Perfluoroethyl. Chem. Eur. J. 2016, $22,417-424$.

(24) Santschi, N.; Togni, A. Hypervalent lodine-based Trifluoromethylating Agents Made in Switzerland. Chimia 2014, 68, 419-424.

(25) Katayev, D.; Václavík, J.; Brüning, F.; Commarea B.; Togni, A. Synthesis of Quaternary $\alpha-$ Perfluoroalkyl Lactams via Electrophilic Perfluoroalkylation. Chem Commun. 2016, 52, 40494052. 


\section{TOC}
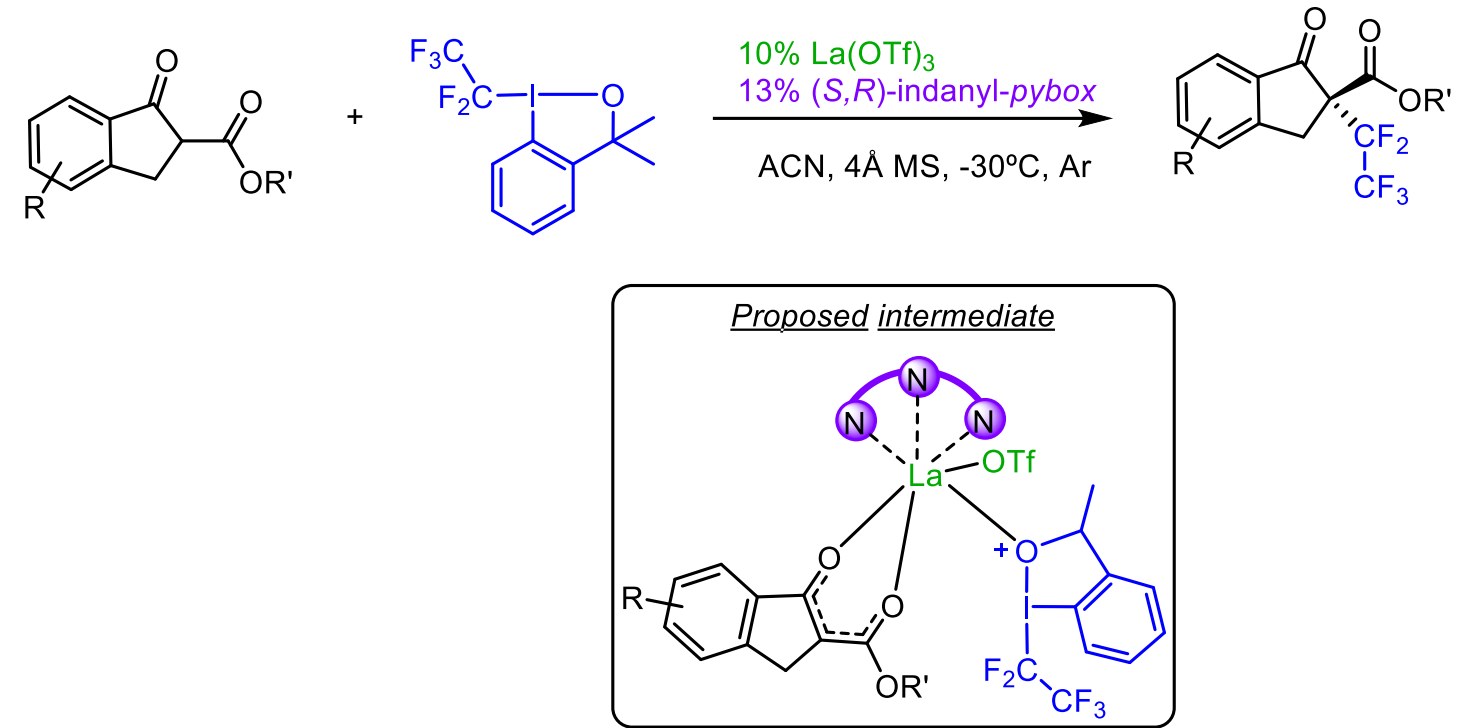